\title{
ASIAN-AFRICAN LEGAL CONSULTATIVE COMMITTEE ANNUAL SURVEY OF ACTIVITIES 1994-1995, including the work of its Thirty-fourth Session, held in Doha (Qatar), 17-22 April $1995^{*}$
}

M.C.W. Pinto**

1. Membership and organization

Paragraphs

Future role of AALCC

2. Questions under consideration by the International Law Commission 9

2.1 Draft Code of Crimes against the Peace and Security of

2.2 Law of the non-navigational uses of international watercourses

3. Legal problems referred to the Committee by participating States

3.1 The status and treatment of refugees

3.3 Law of the sea

3.4 Deportation of Palestinians in violation of international law, particularly the Geneva Convention of 1949 and the massive immigration and settlement of Jews in the occupied territories

4. Matters of common concern having legal implications

4.1 The United Nations Conference on Environment and Development: follow-up

$\begin{array}{llr}4.2 & \text { United Nations Decade of International Law } & 58-60 \\ 4.3 & \text { 'Agenda for Peace' }\end{array}$

4.4 Trade Law: Progress Report concerning the Legislative Activities of the United Nations and Other International Organizations in the field of International Trade Law

\footnotetext{
* The account of the main activities of the Committee and the main views expressed during or in connection with the Committee's Thirty-fourth Session has been adapted from (the unpublished version of) the Secretariat's Report of the Thirty-fourth Session ('Report'). Since 1994 the Secretariat published "Asian-African Legal Consultative Committee: Report and Selected Documents of the [. . .] Session".

** General Editor
} 


\section{MEMBERSHIP AND ORGANIZATION}

1. There were forty-three Members of the Committee on 17 April 1996: Bahrain, Bangladesh, China, Cyprus, Egypt, Gambia, Ghana, India, Indonesia, Iran, Iraq, Japan, Jordan, Kenya, Democratic People's Republic of Korea, Republic of Korea, Kuwait, Libya, Malaysia, Mauritius, Mongolia, Myanmar, Nepal, Nigeria, Oman, Pakistan, Palestine, Philippines, Qatar, Saudi Arabia, Senegal, Sierra Leone, Singapore, Somalia, Sri Lanka, Sudan, Syria, Tanzania, Thailand, Turkey, Uganda, United Arab Emirates, and Yemen. Botswana is an Associate Member.

2. The Thirty-fourth Session of the Committee was held in Doha from 17-22 April 1995 at the invitation of the Government of Qatar. H.H. Sheikh HAMAD BIN KHALIFA AL-THANI, the Heir Apparent and Minister of Defence of Qatar delivered the inaugural address, and H.E. Sheikh AHMED BIN SAIF AL-THANI, Minister of Justice of Qatar, an address of welcome. H.E. Dr. NAJEEB MOHAMMED AL-NAUIMI, Minister Legal Adviser to the Heir Apparent of Qatar was elected President, and the Honourable ABDELAZIZ ABADALLA SHIDDO, Minister of Justice and Attorney-General of Sudan was elected VicePresident of the Committee. The Secretary-General of the Committee, Mr. TANG CHENGYuAN, and the members of the AALCC Secretariat were responsible for the organization of the Session.

3. Subsequent to the meeting in Doha, the Committee decided to accept the invitation of the Philippines to hold its Thirty-fifth Session in Manila from 4-9 March 1996.

\section{Future role of AALCC}

4. In the course of general statements made at the commencement of the Session, several delegates made observations concerning the role of AALCC. The delegate of Indonesia noted that the 40th anniversary of the historic AsianAfrican Conference held at Bandung would be celebrated on 24 April 1995, and recalled the Ten Principles of international relations ${ }^{1}$ formulated there,

\footnotetext{
1 “. . . Free from mistrust and fear, and with confidence and goodwill towards each other, nations should practise tolerance and live together in peace with one another as good neighbours and develop friendly co-operation on the basis of the following principles:

1. Respect for fundamental human rights and for the purposes and principles of the Charter of the United Nations.

2. Respect for the sovereignty and territorial integrity of all nations.
} 
which had later been recognized as the basic philosophy of the Non-aligned Movement when it came into being in Belgrade in 1961. He called for continued solidarity among Asian and African countries to ensure that a "new world order" would not re-impose old patterns of dominance. He urged that AALCC, which had been established following the Bandung Conference, intensify its role in promoting the dissemination and progressive development of international law.

5. The delegate of China recalled that AALCC had come into being under the guidance of the Bandung spirit which had been based on the Five Principles of Peaceful Co-existence and other universally recognized norms governing international relations. He urged that AALCC continue in its positive role of providing a forum for consultations on international legal issues of common interest so as to strengthen understanding and coordination among Member States. The delegate of Korea said that AALCC should continue to promote common awareness of the merit of peaceful resolution of disputes, as well as the development of consensus on regional and global issues among its Members.

6. While emphasizing AALCC's achievements in the past, and praising the work of its Staff under successive Secretaries-General, several delegates made specific suggestions as to the Committee's future role. Thus, the delegate of India stressed the importance of establishing priorities when dealing with a wide range of topics in a short period of time. In his opinion, discussion at the

3. Recognition of the equality of all races and of the equality of all nations large and small.

4. Abstention from intervention or interference in the internal affairs of another country.

5. Respect for the right of each nation to defend itself singly or collectively, in conformity with the Charter of the United Nations.

6. (a) Abstention from the use of arrangements of collective defence to serve the particular interests of any of the big powers.

(b) Abstention by any country from exerting pressure on other countries.

7. Refraining from acts or threats of aggression or the use of force against the territorial integrity or political independence of any country.

8. Settlement of all international disputes by peaceful means, such as negotiation, conciliation, arbitration or judicial settlement as well as other peaceful means of the parties' own choice, in conformity with the Charter of the United Nations.

9. Promotion of mutual interests and co-operation.

10. Respect for justice and international obligations.

The Asian and African Conference declares its conviction that friendly cooperation in accordance with these principles would effectively contribute to the maintenance and promotion of international peace and security, while co-operation in the economic, social and cultural fields would help bring about the common prosperity and well-being of all. . ." (From Part G of the Final Communique of the Asian-African Conference, issued 24 April 1955). 
Committee's meetings should focus on broader issues of long-term significance rather than those which concerned one or two Members, and on technical and legal issues, rather than on political aspects. The delegate of Uganda urged that there be consultations regarding the Committee's agenda, followed by a focus on specific issues which should be studied in depth. The delegate of Egypt suggested that a Co-ordinating Committee be formed, composed of the current President, the outgoing President and one other member, with a view to making AALCC more effective, and implementing its decisions. The delegate of Sudan called for a re-formulation of AALCC's role to enable it to be more effective in international fora, and in particular, in checking the use of the United Nations as a tool by some countries. The necessary changes could, in his view, be effected through modifying the bye-laws and regulations of AALCC. The delegate of Ghana urged that future sessions of the Committee should be timed to facilitate maximum participation, and should not coincide with major religious events.

7. Among the topics suggested for future study by the Committee were: environment and development, including biological diversity and climate change; legal issues concerning trade, and the need for arbitration centres and other institutional machinery for settling disputes to take into account differences in the trade and commercial practices among countries; international rivers; the status of refugees and displaced persons; and the proposal to establish an International Criminal Court.

8. The delegate of Syria proposed that the Committee make "an academic study about International Nuclear Law which should determine rights and duties of nuclear and non-nuclear States". The delegate of Jordan referred to the need to free the Middle East from nuclear weapons through a proper regulatory mechanism.

\section{QUESTIONS UNDER CONSIDERATION BY THE INTERNATIONAL LAW COMMISSION}

9. The Committee had before it the following Secretariat documents: Report on the Work of the International Law Commission at its Forty-sixth Session (Doc. No. AALCC/XXXIV/DOHA/95/1) containing surveys of the Commission's work on four topics, viz. the Draft Code of Crimes against the Peace and Security of Mankind, including the Draft Statute for an International Criminal Court, law of the non-navigational uses of international watercourses, international liability for injurious consequences arising out of acts not prohibited by international law, and State responsibility; and International 
Criminal Court: an update (Doc. No. AALCC/XXXIV/DOHA/95/1A) containing a summary of the views expressed on the subject by representatives in the Sixth (Legal) Committee of the General Assembly at its Forty-ninth Session in 1994, and a report on a Seminar on the subject organized by AALCC in collaboration with the Indian Society of International Law in New Delhi on 12 January 1995 .

\subsection{Draft Code of Crimes against the Peace and Security of Mankind: the establishment of an International Criminal Court}

10. The delegate of Japan reporting on the ad hoc meeting on the International Criminal Court (ICC) which had convened in New York from 3-13 April 1995, said that discussion there had focussed on four major sets of issues. As to organizational aspects, he said that most countries had favoured establishment of the ICC by a treaty requiring ratification by a substantial number of States for its entry into force, and having its relationship to the United Nations governed by agreement between the two institutions. As to jurisdiction, representatives had emphasized the principles nullum crimen sine lege and non bis in idem, and had expressed the view that the description of crimes listed in article 20 of the draft Statute were too vague to be applied in the administration of criminal justice. He noted that there had been no consensus on the role of the Security Council in relation to such matters. As to procedure and due process, he said there had been a consensus that criminal procedures should not be left to be drawn up by the judges of the ICC as suggested by the Commission, but should be drafted and approved by States, and that an expert group had been established for the purpose. As to budget and administration he said opinions had been divided, some States preferring that States Parties to the treaty establishing the ICC should finance it, while others proposed that the ICC should be financed out of the regular budget of the United Nations. He noted that some of the issues referred to would be discussed in depth at a meeting to take place in August 1995.

11. The delegate of Sri Lanka said that any international criminal court established should function with strict impartiality on the basis of objective criteria, and stressed that in defining its jurisdiction the sovereignty and territorial integrity of States had to be respected. The delegates of Sudan and Republic of Korea expressed similar views.

12. The delegate of China observed that the question of the establishment of an international criminal court was politically sensitive and legally and technically complicated. He emphasized that domestic courts would continue to play a primary role in the administration of criminal justice, and any 
international court that might be established should have only a complementary role. In his view, the jurisdiction of such a court could only be based on the consent of States and the voluntary submission of cases by them. Several issues connected with the subject still remained to be resolved, including the role of the Security Council, and in his view no diplomatic conference to establish the ICC should be convened until the conditions for it were right, and a general consensus had been reached concerning the draft Statute.

13. The delegate of Ghana conceded that there might be a need for an international criminal court and that such a court could play an important role in a new world political and economic order. However, he had observed a certain element of discrimination in the way some countries viewed the occurrence of serious crimes in different regions of the world. Crimes of an international nature committed in Africa had evoked less interest than similar crimes occurring elsewhere. For that reason the relationship between the ICC and the United Nations was important, and ought to be the subject of a careful study by AALCC. He emphasized that trial by a municipal court should be recognized internationally, and the principle of double jeopardy applied. He proposed that the issue of intervention by regional or sub-regional organizations in the event of an absolute breakdown of governmental functions resulting in mass suffering and death, should also be studied by AALCC with a view to drawing up guidelines on what might constitute legitimate intervention.

14. The delegate of India observed that the Draft Code of Crimes against the Peace and Security of Mankind was no less important than the Draft Statute of the International Criminal Court, and that both raised issues that were in need of further careful study. He emphasized that whatever the procedure ultimately adopted, it would be necessary to respect the primacy of national jurisdiction.

15. The delegate of Pakistan noted that there were still divergent views on many important issues concerning establishment of the ICC, in particular, on whether the Court's jurisdiction should be compulsory or consensual; whether it should be exclusive, concurrent, or of a review character; and whether it should be linked to the Draft Code or not. It also remained to be decided who would have standing to bring a complaint before the Court, and whether State consent would be required before the complaint could be entertained. Continuing, the delegate stressed that offences and the punishments provided for them had to be clearly defined, noting that investigation would be carried out under the local law of the States concerned. In his view, a code of criminal procedure should provide inter alia for: the registration of crimes, arrest of the 
accused, interrogation of the accused and suspects, recording of the statements of witnesses, recovery of articles used in the commission of a crime, the taking of expert evidence when required, the treatment accorded to confessions, and the recording of pre-trial statements by witnesses. The powers and functions of prosecutors and investigating officers would also need clear definition. Adequate safeguards should be provided for the rights of the accused, dealing with matters such as the place of the trial, defence by competent counsel, and the language to be used in the proceedings. It would also, in his view, be necessary to adopt a code relating to evidence so as to be able to distinguish between admissible and inadmissible evidence at the time of the trial. He observed that measures such as he had outlined could result in the need for States to amend their laws, and that this might not be acceptable to many.

\subsection{Law of the non-navigational uses of international watercourses}

16. The delegate of Syria said that he favoured adoption of the Commission's draft on the non-navigational uses of international watercourses as a framework convention. He offered the following observations regarding the draft for consideration by the Committee: (1) the articles should be applied to cases of closed groundwater constituting a hydrological unitary whole; (2) the definition of the term "international watercourses" in Article 2 should be maintained, and the words "flowing into a common terminus" should not be deleted; (3) the interpretation of what constitutes "equitable and reasonable utilization and participation" should be added in the text of Article 5; (4) provision should be made in Article 17 of the draft for the appointment of an international observer if one of the watercourse States found this to be necessary; (5) he could agree that the principle incorporated in Article 16 prohibiting causing harm to others, should apply to confined groundwater; and (6) a new article, i.e. Article 34, should be added, which would acknowledge "water" as being equal in value with "territory" and therefore protected by the provisions relating to "territory" in the United Nations Charter.

\section{Decision}

17. Discussion of this item (Report, pages 48-60) was followed by adoption of an essentially procedural decision (Report, pages 96-7). 


\section{LEGAL PROBLEMS REFERRED TO THE COMMITTEE BY PAR- TICIPATING STATES}

\subsection{The status and treatment of refugees}

18. The Committee had before it two documents prepared by the Secretariat in consultation with the office of the UN High Commissioner for Refugees: "Model legislation on the status and treatment of refugees" (Doc. No. AALCC/XXXIV/DOHA/95/2); and "Establishment of safety zones for displaced persons in their country of origin" (Doc. No. AALCC/XXXIV/ DOHA/95/3. The documents represent substantial advances in the study of these topics on the basis of guidance offered by Member States at earlier sessions of the Committee (as to model legislation, see 4 AsYIL pp. 339-343; and as to safety zones, ibid., pp. 343-354), and in the course of inter-sessional consultations engaged in by the Secretariat.

19. Document DOHA/95/2, having outlined the history of the treatment of its subject by the Committee, and emphasizing the "necessity for ratification of the 1951 Convention relating to the Status of Refugees", goes on to present the draft text of a model law entitled "An act for the recognition and protection of persons who seek refugee status within the territory of this country". The draft text, and the commentary which precedes it, are reproduced below.

“. .

\section{MODEL LEGISLATION}

A. Structure

B. General Provisions

(i) Basic principles

(a) Non-refoulement

(b) Non-discrimination

(c) Family unity

(ii) Definition of refugee

(iii) Exclusion clause

(iv) Cessation clause

C. Rights and Obligations of Refugees

(i) Rights of refugees

(ii) Established standards of treatment

(a) National treatment

(b) Treatment accorded to nationals of habitual residence 
(c) Most-favoured-nation treatment

(d) Treatment not less favourable than that accorded to aliens

(iii) Obligations of refugees

(iv) Provisional measures

D. Organizational Arrangements

\section{MODEL LEGISLATION}

\section{A. Structure}

22. The Model Legislation on the Status and Treatment of Refugees proposed by the Secretariat comprises a preamble and Thirty-one sections arranged in Three Parts viz. General Provisions; (Sections 1-9); Rights and Obligations (of refugees) (Sections 10-24); and Organizational Arrangements (Sections 25-31). Read together they set out the scope ratione personea, and ratione materiae, of the proposed legislation and also provide for the establishment of an administrative/executive organ to deal with matters relating to refugee status determination and rights and duties of refugees in the receiving State. The last part also makes provision for quasi-judicial or judicial review of decisions in matters relating to the status of refugees. The text of the Model Legislation on the Status and Treatment of Refugees prepared by the Secretariat (See Annex) has already been circulated among Member States.

\section{B. General Provisions (Sections 1-9)}

23. Part I of the Model Legislation comprising nine sections addresses itself to such matters as (i) title, purpose and scope of the proposed Act (Section 13); (ii) definitions or use of terms (Section 4); (iii) the basic principles of the treatment of refugees (Section 5); (iv) meaning of the term 'refugees' (Section 7); (v) determination of a class of persons as refugees (Section 7), and (vi) exclusion and cessation clauses (Section 8-9). Sections 1 and 3 dealing with the title and territorial applicability of the proposed legislation are selfexplanatory and require no comment.

24. Section 2 of the proposed legislation in setting out the purpose seeks to reinforce and fortify the norm identified in the preamble of the proposed legislation i.e. the protection of persons who seek refuge. One criticism hitherto levelled against the legislative approach adopted by States to regulate refugees has been that the issue of refugee protection is approached as one of defining not the rights (of the refugees) themselves but rather the powers vested in refugee officials. It has been argued in this regard that the protection of refugees' rights becomes an exercise of powers and discretion of those officials rather than enforcement of specific rights identified and generalized 
by law. In other cases, it is further argued, the realization of refugee rights is left to depend ultimately on an exercise of Ministerial discretion.

25. Mindful of this lacuna in some of the existing national legislation the AALCC Secretariat has proposed describing of the purpose of the Act as establishing "a procedure for granting of refugee status to asylum seekers, to guarantee to them fair and due treatment and to establish the requisite machinery therefore".

\section{(i) Basic principles}

26. Section 5 of the Model Legislation whilst enumerating the basic principles of the treatment of refugees seeks to ensure that an asylum seeker receives fair and due treatment from state officials engaged in relief and assistance work for refugees. The other principles enumerated in this section are non-refoulement, non-discrimination, and the principle of family unity.

\section{(a) Non-refoulement}

27. The principle of non-refoulement has been incorporated in all regional and international instruments relating to the status and treatment of refugees, including the AALCC Bangkok Principles and thus requires no explanation or justification for its inclusion. It may be stated, however, that the principle of non-refoulement is neither absolute nor universal. The clauses allowing exceptions to the principle of non-refoulement incorporated in the 1951 Convention, the 1967 Declaration on Territorial Asylum as well as the Bangkok Principles, 1966 are a pointer that this principle is not absolute. In Japan - which acceded to the 1951 Convention - the Courts are known to allow refoulement when the Minister of justice finds the application of the principle of non-refoulement "seriously detrimental to the interests of Japan and security thereof".

\section{(b) Non-discrimination}

28. The principle of non-discrimination has hitherto been incorporated in the Universal Declaration of Human Rights, 1948 and OAU Convention Governing the Specific Aspects of Refugee Problems in Africa, 1969. The International Convention on the Elimination of all Forms of Racial Discrimination, 1955, the International Covenant on Civil and Political Rights, 1966 and the practice of States more than affirm that the principle of nondiscrimination is a generally accepted principle of international law and that discriminatory practices of States are not permissible. However, in as much as the reference to a "membership of a particular social group or political opinions" found in Article IV of the OAU Convention is omitted in the present 
clause the principle of non-discrimination incorporated herein may be considered as narrow and restricted in its scope and therefore may require further consideration.

\section{(c) Family unity}

29. As regards the principle of family unity, it draws its strength from the Universal Declaration of Human Rights, 1948, the practice of competent international organizations in the field of humanitarian affairs as well as from the practice of States. The International Covenant on Economic, Social and Cultural Rights 1966; the International Convention on the Protection of all Migrant Workers and Members of their Families, 1990 and the 1984 Declaration of Cartagena adopted by Central and South American States and the African Charter on Human and People's Rights, 1981 all incorporate the principle of family unity. It may be stated that the concept of family unity may be found in Article 37 of the Vienna Convention on Diplomatic Relations, 1961, which admits of and allows immunity in respect of the family of a diplomatic agent. More recently the Convention on the Rights of the Child, 1990 reaffirmed the principle of family unity.

(ii) Definition of refugee (Sections 6 and 7)

30. Sections 6 and 7 define the scope ratione personae of the proposed legislation and are at the core of the matter of refugee status determination both in respect of individuals and - in the event of a large influx - the determination of the status of a group or class of persons as refugees.

Historically, the term 'refugee' was used in various instruments prior to 1951 to refer to the ethnic or territorial origins of different uprooted groups, and to their loss of national protection. There was in those instruments no reference to persecution in the sense that this term is currently employed.

31. The first formal reference to persecution as part of the refugee definition came in the 1946 Constitution of the International Refugee Organization (hereinafter called the IRO), a temporary specialized agency of the United Nations and the predecessor of UNHCR. Paragraph 7(a)(i) of Section C of the Constitution of the IRO referred to a "persecution or fear, based on reasonable grounds owing to race, religion, nationality or political opinions" [ footnote: Section B] as being a valid objection to repatriation. Paragraph 3 of Section A of part I extended IRO's competence to the "victims of Nazi persecution" still within their country of origin. IRO's Constitution also made reference for the first time to 'displaced persons' as well as refugees - a concept which came to be extensively applied to UNHCR's mandate. 
32. Thereafter the United Nations Declaration of Human Rights in 1948 alluded to everyone's right to seek asylum from 'persecution', without further defining the term, and the General Assembly employed the term "well-founded fear of persecution" for specified reasons as the central criterion in determining the ambit of UNHCR's Statute.

33. This definition was essentially repeated in the 1951 Convention Relating to the Status of Refugee while its application was limited to victims of persecution as a result of events occurring before January, 1951. The extent and scope of the term 'refugee' was, however, expanded in as much as it included "membership of a social group" as one of the possible causes of persecution. States parties could also, if they desired, restrict the causative events to those occurring in Europe. The 1967 Protocol to the Convention removed both the temporal limitation as well as the optional geographic limitation from this definition.

34. The definitions of the 'refugee' in the Convention and Protocol have, since 1967, remained unchanged, although it may be recalled that Recommendation E of the Final Act of the Conference of Plenipotentiaries which adopted the Convention in 1951, urged all States parties to extend its benefits as far as possible to persons who did not fall within its strict ambit. While this, of course, is not binding on States it is indicative of the general agreement, at that time, of the need for a liberal interpretation of the term 'refugee', by States in determining who should receive international protection.

35. This need also became very apparent in regard to UNHCR's activities, and by the 1960's the need for groups outside the original statutory definition to be assisted was clear, particularly in the wake of the General Assembly Resolution on the Granting of independence to Colonial Peoples and the independence movements in Africa.

36. Consequently there were a series of General Assembly resolutions, extending over the next two decades, which formally endorsed the High Commissioner's involvement with a much broader category of exiles. Thus in 1959 the General Assembly requested the High Commissioner to use his 'good offices' to transmit contributions to "refugees not within the competence of the United Nations" (without defining this phrase further). Then from 1961 to 1963 a series of General Assembly resolutions endorsed UNHCR activities for refugees within the High Commissioner's mandate "or those for whom he extends his good offices".

37. This liberalizing trend was reinforced in 1969 by the OAU Convention Governing the Specific Aspects of Refugee problems in Africa, which added to the statutory refugee definition an important expansion of the term in so far as it applied in Africa, viz., that: 


\begin{abstract}
“'Refugee' shall also apply to every person who, owing to external aggression, occupation, foreign domination or events seriously disturbing public order in either part or the whole of his country of origin or nationality, is compelled to leave his place of habitual residence in order to seek refuge in other place outside his country of origin or nationality."
\end{abstract}

This expanded definition remains the most formal extension of the refugee concept accepted by Governments, as has, following proposals made at the Arusha Conference on Refugees in Africa in 1979, been endorsed by the General Assembly as applying to UNHCR's activities in the African continent.

38. Sections 6 and 7 of the model legislation are based on these considerations. An additional factor in favour of the term refugee adopted in section 6 is that most of the African States that have during the 1980's enacted legislation relating to the status and treatment of refugees have adopted somewhat similar definitions.

\title{
(iii) Exclusion clause (Section 8)
}

39. The previous conduct of an asylum seeker is a significant input in the decision concerning this refugee status to the point of automatically excluding him from the protective umbrella of the international instruments, e.g. where a person has committed a crime against peace, a war crime or a crime against humanity or a serious non-political crime outside the country of refuge prior to his admission to that country as a refugee, or has been guilty of acts contrary to the Purposes and Principles of the United Nations. Nor can the benefit of the principle of non-refoulement be claimed by a person who on reasonable grounds is regarded as a danger to the security of the country in which he is, or who having been convicted by a final judgement of particularly serious crime, constitutes a danger to the community of that country. Such serious offences as the Unlawful Seizures of Aircraft, the Taking of Hostages and murder are just and fair grounds for extradition or expulsion of the individual.

40. This exclusion clause as incorporated in Article $1(F)$ of the 1951 Convention has since been adopted in several national laws, for instance Article 8 of the Malawi Refugee Act, 1989; Section 3(4) of the Zimbabwe Refugee Act, 1983 and Section 3(2) of the Lesotho Refugee Act 1989. Article 33 paragraph 2 of the 1951 Convention, Article 3 of the General Assembly Declaration on Territorial Asylum, 1967 and the 1966 Bangkok Principles are among the instruments which affirm the exception to the rule of nonrefoulement. In sum, the principle of non-refoulement is not absolute and the term 'refugee' excludes fugitives from justice. 
41. Among the primary duties of a refugee is not to have committed a common crime. For if he has, he can be excluded from the country of refuge. The aim of the exclusion clause Article $1(\mathrm{~F})$ of the Convention, is to protect the community of a receiving country from the danger of admitting a refugee who has committed a serious crime and to ensure that he does not enjoy the benefit of refugee status so as to exonerate himself from justice. It also seeks to render due justice to a refugee who has committed a common crime of a less serious nature or has committed a political offence. Only a crime committed or presumed to have been committed by an applicant "outside the country of refuge prior to his admission to that country as a refugee" is a ground for exclusion.

42. A refugee committing a serious crime in the country of refuge is subject to due progress of law in that country. Article 32 of the 1951 Geneva Convention provides that a refugee lawfully in the territory of a contracting State shall not be expelled "save on grounds of national security or public order". Such a refugee shall be expelled only in pursuance of a decision reached in accordance with due process of law. Except where compelling reasons of national security otherwise require the refugee shall be allowed to submit evidence to clear himself, and to appeal to and be represented for the purpose before competent authority". Article 33, which prohibits expulsion or return, however, provides in paragraph 2 that under extreme circumstances a refugee may be expelled when "there are reasonable grounds for regarding (him) as a danger to the security of the country in which he is, or who, having been convicted by a final judgment of a particularly serious crime constitutes a danger to the community of that country".

\section{(iv) Cessation clause}

43. When the circumstances in connection with which a person has been recognized as a refugee have ceased to exist he can no longer continue to refuse to avail himself of the protection of the country of his nationality or return to the country of his nationality or to return to the country of his habitual residence. In such case the 1951 Convention ceases to apply. The Convention a fortiori does not apply to persons receiving protection or assistance from organs or agencies other than the UNHCR. This cessation clause of the 1951 Convention has, inter alia, been incorporated in section 3 paragraph 5(1)(a) of the Zimbabwe Refugee Act 1983 and Article 4 of the Lesotho Refugee Act, 1983.

44. The Statute of the UNHCR envisages, it may be recalled, two forms of permanent solution for the problem of refugee viz. voluntary repatriation or their assimilation into new national communities. Paras a, b, and c of Section 9 of the proposed model conform to these objectives and draw strength, inter alia, from Article II of the AALCC Bangkok Principles, 1966. 
C. Rights and Obligations of Refugees (Sections 10-24)

\section{(i) Rights of refugees}

45. Part II of the Model Legislation comprising fifteen sections (10 to 24) addresses itself to the Rights and Obligations of Refugees whilst in the territories of the State affording them protection. The first of these viz. section 10 addressed to the rights of refugees offers alternative formulations. Option A is based on the express recognition of all rights set out in the regional and universal conventions to which the State is a party and recognizes and accepts the references to the term 'refugees' in those instruments as references to refugees recognized and protected by and under the proposed Act. This formulation draws its inspiration from Section 12 of the Zimbabwe Refugee Act, 1983. This alternative would require that either the specific provisions of the instruments which are to be given effect be set out in a schedule or annexed to the proposed act or to be identified and included in the corpus of the Statute.

46. The second alternative i.e. option B is somewhat restrictive in its scope of application and apart from fair and due treatment without discrimination restricts the rights of the refugees to those that are generally accorded to aliens in particular to such matters as right to property, right to transfer assets, and the rights to engage in agriculture, industry etc. It may be recalled in this regard that the Bangkok Principles concerning Treatment of Refugees adopted by the AALCC had included the minimum standard of treatment and that Article VI of those Principles provided, inter alia, that a State shall accord to refugees treatment in no way less favourable than that accorded to aliens and that the standard of the treatment shall include the rights relating to aliens to the extent that they are applicable to refugees.

47. A refugee whether he is in the territory of the State of asylum, in transit, or in the receiving State for resettlement enjoys certain basic civil rights. Article 14(1) of the Universal Declaration of Human Rights stipulates: "Everyone has the right to seek and to enjoy in other countries asylum from persecution". The Preamble to the 1951 Convention Relating of Refugees reaffirms that "human beings shall enjoy fundamental rights and freedoms without discrimination" and endeavours to assure refugees the widest possible exercise of these fundamental rights and freedoms.

48. The rights and protection to be afforded or granted to a refugee by a State are obligatory not only under the Convention but also under customary international law and general principles recognized by nations. It may be recalled in this regard that the Bangkok Principles adopted by the AALCC in 1966 recognize this principle, and a State party to the 1951 Geneva Convention and its Protocol thereto is obliged to grant the protection and rights to the 
refugees as described in the instruments. The 1951 Geneva Convention primarily codified the then existing international custom and general principles of law on the international legal rights and obligations of refugees.

\section{(ii) Established standards of treatment}

49. While the Convention on Refugees 1951 envisages the same treatment as is accorded to aliens generally, it goes a little further with respect to some specific rights, in respect of which refugees are granted more favourable treatment than that accorded to aliens. the four established standards of treatment are:(i) national treatment i.e. the treatment accorded to nationals; (ii) treatment accorded to nationals of the country of habitual residence; (iii) Mostfavoured-nation treatment accorded to nationals of a foreign country; and (iv) treatment as favourable as possible and, in any event, not less favourable than that accorded to aliens generally in the same circumstances.

\section{(a) National treatment}

50. This standard is generally accorded to refugees as regards (a) freedom to practice their religion and the religious education of their children (Article 4); (b) access to courts (Article 16, paragraphs 1 and 2); (c) wage-earning employment of refugees who have completed three years residence in the country or who have spouse or one or more children possessing the nationality of the country (Article 17, paragraph 2); rationing (Article 20) (e) elementary education (Article 22, paragraph 1); (f) the right to public relief and assistance (Article 23); (g) matters of labour legislation and social security (Article 24) and (h) taxation (Article 29).

\section{(b) Treatment accorded to nationals of habitual residence}

51. This treatment is accorded to refugees with regard to (a) the protection of their intellectual property, such as inventions, trade marks and trade names, and of their rights in literary, artistic and scientific works (Article 14), (b) access to courts, (c) legal assistance and (d) exemption from cautio judicatum solvi in countries other than that of their habitual residence (Article 16, paragraph 3).

\section{(c) Most-favoured-nation treatment}

52. This treatment is granted to refugees as regards (a) their right to form and to join non-political and non-profit making associations and trade unions (Article 15), (b) the right to engage in wage-earning employment, if the refugees concerned do not fulfil the conditions necessary for the enjoyment of national treatment (Article 17, paragraph 1). 
(d) Treatment not less favourable than that accorded to aliens

53. The principle of treatment as favourable as possible and in any event not less favourable then that accorded to aliens is applied to refugees with regard to (a) acquisition of movable and immovable property, property rights and interests (Article 13); (b) the right to engage on their own account in agriculture, industry handicrafts and commerce, and to establish commercial and industrial companies (Article 18), (c) to practice liberal professions (Article 19); (d) to obtain housing (Article 21); and (e) to benefit from higher education (Article 22, paragraph 2)

\section{(iii) Obligations of refugees (Section 12)}

54. The principle of national sovereignty requires that all persons including refugees, conform to the laws and regulations of the country of asylum as well as to the measures taken for maintenance of public order. Section 11 of the Model Legislation draws its strength from Article 2 of the 1951 Convention and Article 3 of the OAU Convention of 1969.

\section{(iv) Provisional measures (Section 14)}

55. Article 8 of the 1951 Convention stipulates that in time of war or other grave and exceptional circumstances a State may take provisional measures essential to national security in the case of a particular person pending a determination that the person is in fact a refugee and that the continuance of such measures is necessary in his case in the interest of national security. The stipulation of Article 8 of the Convention Relating to the Status of Refugees, 1951 should be read together with Article 44 of the Fourth Geneva Convention relative to the Protection of Civilian Persons in Time of War, 1949. Article 44 of the Fourth Geneva Convention, inter alia, stipulates that in applying the measures of control the power in whose jurisdiction protected persons find themselves shall not treat refugees as enemy aliens, exclusively on the basis of their nationality.

\section{Organizational Arrangements (Sections 25-36)}

56. States generally determine their own policies regarding the admission of refugees and displaced persons and there are no international conventions which require the admission of refugees and displaced persons. States are free to enact their own laws and regulations governing such admissions. In deciding whom to admit States are often guided by generally acceptable humanitarian principles of international law.

57. Several States are also known to screen refugees at the border and many reject refugees without any procedural review. The right of refugees to appeal 
adverse or negative refugee status determination is unevenly available. According to a UNHCR report on the procedures employed by States Parties to the 1951 Convention and to the Protocol of 1967 thereto, only 28 States permitted appeals. In Malawi, for instance, any person who is dissatisfied with a decision of the Refugee Committee in regard to his application status or revocation of its decision granting him refugee status may appeal to the Minister and the Minister may confirm, set aside or vary the decision.

58. The two-fold thrust of Part III of the Model Legislation is to provide machinery for refugee status determination by a Bureau/Department/Division or Unit of the receiving State. In practice, however, the refugee status determination machinery varies from State to State. Thus, in Thailand the Government officials in the refugee status determination process for the Vietnamese Boat People were all drawn from the Ministry of Interior, who based their decisions on the recommendations of lawyers and the appeals considered by more senior officials from the same Ministry. In Malaysia the responsibility of refugee status determination both in the initial stages and the review stages was entrusted to the National Task Force for Vietnamese Illegal Immigrants composed of officials from the Army, Navy and Police. There the National Task Force, in turn, is known to have appointed officers to interview asylum seekers and both the first instance and review decisions were taken by senior officials of the National Task Force. In the Philippines the asylum seekers were interviewed and first instance decisions made by immigration officials. Appeals against the first instance decisions were reviewed by an Appeal Board comprising senior Government officials.

59. African State practice is not very divergent. In Nigeria a National Commission for Refugees, an Eligibility Commission and an Appeal Board for refugee status determination and safeguarding the rights of asylum seekers was established in 1989. In Zimbabwe the Refugees Act of 1983 provides that any person who is aggrieved by a refusal of the Commissioner to recognize him as a refugee may appeal in writing to the Minister. The right to appeal against a negative decision of the Commissioner may also be executed in the event of withdrawal of recognition of a person as a refugee. In Malawi too, as mentioned above, any person dissatisfied with a decision in regard to his application for a refugee Status or revocation of the decision granting refugee status to him may appeal to the Minister who may confirm, set aside or vary the decision.

60. The Lesotho Refugee Act incorporates somewhat detailed provisions in this regard and establishes an Inter-ministerial Committee for Determination of Refugee Status, and a Refugee Advisory Board. Under that Act, where the Minister on the advice of the Inter-ministerial Committee for the Determination of Refugee Status decides not to recognize an asylum seeker as a refugee, that person has the right to reapply to the Minister to reconsider his applica- 
tion. The Minister may refer the matter to the Advisory Board who shall then make recommendation on the same to the Minister for a final decision. The Lesotho Act goes on stipulate that where after the reconsidering of the applicant's case the Minister decides to reject the recommendation of the Committee or the Board the applicant shall have the right to seek appropriate relief from the High Court Of Lesotho

61. It is against this backdrop that Part III of the draft of the Model Legislation entitled Organizational Arrangements aims at establishing an institutional and administrative machinery for matters dealing with refugee status determination related matters. This part of the draft proposes the establishment of an executive organ and a review/appellate body for the purpose of judicial or quasi-judicial review of the decisions, or orders of the executive body (Sections, 25,26 and 27). This part also explicitly provides the composition and functions of both the executive organs as well as the review/appellate authority and other matters allied to their functioning. (Sections 28 to 36).

\section{MODEL LEGISLATION ON THE STATUS AND TREATMENT OF REFUGEES}

An Act for the recognition and protection of persons who seek refugee status within the territory of this country.

Be it enacted by (as, for example, the Parliament, or the President and Parliament, etc of the concerned country) as follows:

\section{GENERAL PROVISIONS}

1. Short title. This Act/Law shall be called the Refugees (Recognition and Protection) Act, (year of enactment).

2. Purpose of the Act. The purpose of this act is to establish a procedure for granting of refugee status, to asylum seekers, to guarantee to them fair and due treatment and to establish the requisite machinery therefor.

3. Scope of the Act. This Act shall apply throughout the territory of this State or in such areas of the State as the Government may notify.

4. Definitions. In this Act, unless the next otherwise requires,

(1) 'Asylum seeker' means an alien who in need of protection, seeks recognition and protection as a refugee;

(2) 'Member of his family', in relation to a refugee includes

(a) the spouse(s) of the refugee; 
(b) any unmarried child of the refugee under the age of majority;

(c) the father and mother of the refugee who, by reason of age or disability, are, mainly dependent upon the refugee for support; and

(d) any other person related to the refugee by blood or marriage who is solely dependent upon him;

(3) 'Identity Card' means a document issued under the provisions of this Act to a recognized refugee;

(4) 'Refugee' means a refugee as defined in Article 6;

(5) 'Refugee Committee' means the Committee established as an administrative organ by and under the provisions of this Act;

(6) 'Refugee Appellate Authority' means the appellate authority established by and under the provisions of this Act to hear appeals against orders passed by the Refugee Committee as provided under the rules framed by and under the provisions of this Act;

(7) 'Voluntary repatriation' means the voluntary return of refugees to their country of origin on their own free and voluntary decision;

(8) 'Travel document' means a document which is issued by the Refugee Committee for the purpose of enabling a refugee to travel outside this country in accordance with the procedure established by the rules framed by and under the provisions of this Act;

(9) 'Country of origin' signifies, as appropriate, the refugee's country of nationality, or, if he has no nationality, his country of former habitual residence.

\section{Basic Principles for the Treatment of Refugees}

In the application of this Act due regard shall be had to the following principles:

(a) A refugee shall neither be expelled nor returned to the frontiers of territories where his life or freedom would be threatened.

(b) A refugee shall not be discriminated against on the basis of his race, religion or nationality;

(c) A refugee shall have the right to receive fair and due treatment by the officials of the Government or its agencies who are engaged in relief and assistance work for the refugees;

(d) As far as practicable, the principle of family unity shall be preserved and due consideration shall be given to refugee women and children.

\section{Meaning of refugee}

\section{Option A}

Subject to the provisions of this section a person shall be regarded as a refugee if:

(a) owing to a well-founded fear of being persecuted or prosecuted for reasons of race, religion, nationality, sex, membership of a particular 
group or political opinion, he is outside the country of his nationality and is unable or, owing to such fear, is unwilling to avail himself of the protection of that country; or

(b) not having a nationality and being outside the country, of his former habitual residence, he is unable or, owing to a well-founded fear of being persecuted or prosecuted for reasons of race, religion, membership of a particular social group or political opinion is unwilling to return to it; or

(c) owing to external aggression, occupation, foreign domination, internal conflicts, massive violation of human rights or other events seriously disrupting public order in either part or whole of his country of origin, he is compelled to leave his place of habitual residence in order to seek refuge in another place outside his country of origin; or

(d) he has been considered a refugee under any other law in force at the time of commencement of this Act.

\section{Option B}

The term 'Refugee' shall mean a person who owing to a well-founded fear of being persecuted or prosecuted for reasons of race, religion, nationality, membership of a particular social group or political opinion, is outside the country of his nationality and is unable or, owing to such fear, is unwilling to avail himself of the protection of that country; or who, not having a nationality and being outside the country of his former habitual residence as a result of such event, is unable or, owing to such fear, is unwilling to return to it.

\section{Declaration of class of persons as refugees}

(1) Notwithstanding anything above, the Refugee Committee may declare a class of persons under clauses (a), (b), (c) or (d) of section 6 to be refugees and may at any time amend or revoke such declaration; provided that no such amendment or revocation shall affect the right of any asylum seeker or any other person who is a member of the class of persons concerned and who entered this country before the date of such amendment or revocation, to continue to be regarded as a refugee for the purposes of this Act.

(2) The Refugee Committee shall cause any declaration in terms of this section, and any amendment or revocation thereof, to be publicized in a manner as it considers will best ensure that it is brought to the attention of authorized officers and persons to whom it relates.

\section{Persons not regarded as refugees}

A person shall not be regarded a refugee for the purposes of this Act if:

(a) he is alleged to have-committed a crime against peace and security of mankind, a war crime or a crime against humanity, regardless of the time it was committed; or 
(b) he is alleged to have committed a serious non-political crime outside this country prior to his admission to this country as a refugee.

\section{Persons who shall cease to be refugees}

A person shall cease to be a refugee for the purposes of this Act if:

(a) he voluntarily re-avails himself of the protection of the country of his nationality; or

(b) having lost his nationality, he voluntarily re-acquires it; or

(c) he becomes a citizen of this country or acquires the nationality of some other country and enjoys the protection of the country of his new nationality; or

(d) he can no longer, because the circumstances in connection with which he was recognized as a refugee have ceased to exist; provided that the provisions of this clause shall not apply to a person who satisfies the Refugee Committee that he has compelling reasons, arising out of previous persecution, for refusing to avail himself or so to return as the case may be; or

(e) he is alleged to have committed a serious non-political crime outside this country after his admission into this country as a refugee.

\section{RIGHTS AND OBLIGATIONS}

10. Rights of Refugees

\section{Option A}

The rights of refugees stipulated by International Conventions to which this State is a party and those customarily recognized by States will be respected and guaranteed as far as practicable is possible.

\section{Option B}

Every refugee, for the time he stays within this country shall have the right,

(a) to fair and due treatment, without discrimination as to race, religion, sex or political opinion, or country of origin;

(b) to receive the same treatment as is generally accorded to aliens relating to

(i) movable and immovable property, other similar rights pertaining thereto, and also to leases and other contracts relating to movable and immovable property;

(ii) education, other than elementary education and, in particular, as regards access to studies, the recognition of foreign school certificates, diplomas and degrees, the remission of fees and 
charges, provided, however, he is accorded the same treatment as is accorded to nationals with respect to elementary education;

(iii) the right to transfer assets held and declared by a refugee at the time of his admittance into the country, subject to the laws and regulations;

(iv) the right to engage in agriculture, industry, handicrafts and commerce and establish commercial and industrial companies in accordance with applicable laws and regulations;

(c) have the same right as nationals of this country with respect to practising their religion and the religions education of their children;

(d) to have free access to courts of law, including legal assistance and exemption from cautio judicatum solvi.

11. Obligations of refugees

(1) Every refugee shall conform to the laws of this country.

(2) A refugee shall not engage in activities which may endanger the State security, harm public interests or disrupt public order.

(3) A refugee is prohibited from engaging in activities contrary to the principles of the United Nations in particular from undertaking any political activities within the territory of this country against any country including his country of origin.

\section{Personal status}

(1) The personal status of a refugee shall be governed by the law of the country of his nationality or domicile or by the law of the country of his residence.

(2) Rights acquired by a refugee and dependent on personal status, more particularly rights attaching to marriage, shall be respected by this country, subject to compliance, if this be necessary, with the formalities required by the law of this country, provided that the right in question is one which would have been recognized by the law of this State had he not become a refugee.

\section{Exemption from exceptional measures}

\section{Option A}

With regard to exceptional measures which may be taken against the person, property or interests of nationals of a foreign State, this country shall/may not apply such measures to a refugee who is a national of the said State solely on account of such nationality. 


\section{Option B}

With regard to exceptional measures which may be taken against the person, property or interests of nationals of a foreign State, this country shall in appropriate cases, grant exemptions in favour of such refugees.

\section{Provisional measures}

Nothing in this Act shall prevent the Government, in time of armed conflict or other grave and exceptional circumstances, from taking provisionally measures which it considers to be essential to the national security, in the case of a particular person, pending a determination by the authority concerned that that person is in fact a refugee and that the continuance of such measures is necessary in his case in the interests of national security.

\section{Industrial property and artistic rights}

In respect of the protection of industrial property, such as inventions, patents, designs or models, trade marks, trade names, and of rights in literary, artistic and scientific works, a refugee shall be accorded the same protection as is accorded to nationals of this country.

\section{Right of association}

As regards the right of association refugees lawfully staying in the territory of this country shall/may be accorded the most favourable treatment accorded to aliens, in the same circumstances.

\section{Liberal professions}

Refugees who hold degrees or diplomas recognized by the competent authorities of this country and are desirous of practising a liberal profession, shall be accorded treatment as favourable as possible as is accorded to aliens generally in the same circumstances.

\section{Rationing}

Where a rationing system exists, which regulates the general distribution of essential commodities in short supply, refugees shall be accorded the same treatment as practicable possible as is accorded to nationals/aliens.

\section{Housing}

As regards housing, refugees shall be accorded treatment as favourable and/or as practicable as possible, as is accorded to aliens generally in the same circumstances.

\section{Identity cards}

An identity card shall be issued to any person recognized as a refugee in accordance with sections 6 and 7 of this Act. 


\section{Travel documents}

A refugee lawfully staying in this country shall be issued travel documents for the purpose of travel outside the territory of this country unless compelling reasons of national security or public order otherwise require.

\section{Fiscal charges}

No duties, charges or taxes of any description whatsoever, shall be imposed on refugees, other or higher than those which are levied on nationals in similar situations.

\section{Transfer of acquired assets}

Favourable consideration may be accorded to an application of a refugee for permission to transfer assets which he has acquired by lawful means during his stay in this country.

\section{Families of refugees}

(1) The members of the family of a refugee shall be permitted to enter this country and, subject to the provisions of this Act, shall be entitled to remain herein as long as the refugee is permitted to remain, and necessary documents be issued to them.

(2) Where a member of the family of a refugee within this country ceases to be a member of such family by reason of marriage, attaining the age of majority or the cessation of dependence upon the refugee, he shall be permitted to continue to remain in this country subject to the relevant laws and regulations.

(3) Upon the death of a refugee, or upon his divorce from any spouse, every person who, immediately before such death or divorce was within this country as the member of the family of such a refugee, shall be permitted to continue to remain and regularize his status in accordance with the provisions of this Act or any other applicable law.

(4) Nothing in this section shall prevent a member of the family of a refugee, or a person who has, in terms of sub-sections (2) and (3), been permitted to continue to remain in this country from himself applying for recognition and protection as a refugee under the provisions of this Act.

\section{ORGANIZATIONAL ARRANGEMENTS}

25. In order to implement the provisions of this Act, the Government shall establish or identify, [by notification in the Official Gazette] 


\section{Option A}

(1) A [Division/Bureau/Department/Unit] to receive and consider applications for refugee status and to make decisions; and

(2) A quasi-judicial Authority vested with the power to revise or review the above decisions and to make final orders thereon.

\section{Option $B$}

(1) A Refugee Committee as the principal executive organ; and

(2) an appellate authority to be known as the Refugee Appellate Authority.

26. Composition of Refugee Committee. The Refugee Committee shall consist of the following members, namely:

(a) a high-ranking official designated by the Minister-in-charge of refugee affairs in the Government who shall be its Chairman; and

(b) such number of other officials from the immigration social welfare, law and justice and other relevant departments.

27. Functions of the Refugee Committee. The functions of the Refugee Committee shall include:

(1) to designate such officials as may be necessary to receive and consider applications for refugee status and to grant (or refuse) asylum seekers refugee status according to the relevant provisions of this Act;

(2) to supervise the observance of the refugees rights and duties as stipulated in this Act;

(3) to propose refugee policy and make appropriate proposals and recommendations to the Government concerning the refugee matters; and

(4) to coordinate the activities or policies of the various Government ministries and departments relating to refugees.

\section{Consideration of Applications by the Refugee Committee}

The Refugee Committee shall consider every application referred to it in terms of Article 27 within a reasonable time (sixty days) of the application being so referred. It may, within that period of time make such inquiry or investigation as the Committee may consider necessary.

\section{Withdrawal of refugee status}

(1) if at any time the Refugees Committee considers that there are reasonable grounds for believing that a person who has been recognized as a refugee for the purposes of this Act, should not have been recognized on account of such person having made his application for recognition based on fraud, false and deliberate misrepresentation or any other abusive grounds, the Committee shall cause a written notice 
to be served upon the person whose status as a refugee is under reconsideration,

(a) informing such person of the fact that his status as a refugee is to be reconsidered; and

(b) inviting such person to make written representation to the Committee within a period of fourteen days from the date of service of the notice, regarding his status as a refugee.

(2) The Committee shall consider every written representation made before it and where appropriate the views of the representative of the UNHCR and, may cause such inquiry or investigation to be made as it thinks necessary.

(3) Upon receipt of the report on the inquiry or investigation and after giving an opportunity to the person against whom proceedings are taken, the Refugee Committee may withdraw the recognition of the person concerned as a refugee, and shall cause the person concerned to be notified of the decision in the matter.

(4) Any person who is aggrieved by the decision of the Refugee Committee withdrawing his recognition as a refugee may, within fourteen days of being notified of such withdrawal, appeal to the Refugees Appellate Authority.

(5) If a decision is taken to withdraw the status of refugee he should be given an opportunity to remove himself from this country or to get his status regularized under any other law of this country.

30. Expulsion of refugees

(1) The Refugee Committee may order expulsion of any refugee in accordance with relevant laws and procedures if it considers it to be necessary or desirable on grounds of national security or public order.

(2) Before making an order in terms of subsection (1), the Refugee Committee shall cause a written notice to be secured upon every refugee whom it intends to expel and affording him the right to make a representation to the Committee.

(3) Before ordering expulsion of any refugee under sub-section (1) the representative of the UNHCR shall be informed.

\section{APPELLATE AUTHORITY}

\section{Refugee Appellate Authority}

The Government may, by notification in the Official Gazette, establish with effect from such date as it may specify an appellate authority to be known as the Refugee Appellate Authority.

\section{Composition of the Refugee Appellate Authority}

The Refugee Appellate Authority shall consist of 
(a) an eminent person preferably a jurist (judge of the Supreme Court) who shall be its President; and

(b) four other members who shall have adequate knowledge or experience of dealing with matters relating to immigration, foreign affairs and national security.

\section{Jurisdiction of the Refugees Appellate Authority}

(1) The Refugee Appellate Authority shall have exclusive jurisdiction over all matters arising out of the application, interpretation and implementation of the provisions of this Act.

(2) Any asylum seeker or, as the case may be, any refugee aggrieved by any order made by the Refugee Committee in respect of sections 29 and 30 may appeal to the Refugee Appellate Authority within fourteen days from the date of the order;

provided that the Refugee Appellate Authority may enter appeal after the expiry of the stipulated period if it is satisfied that there was justifiable cause for not filing it within that period.

\section{Power to make rules and disposal of appeals}

The Refugee Appellate Authority shall determine its own rules of procedure relating to matters referred to it. In so far as possible the Refugee Appellate Authority shall dispose of an appeal made before it within a period of sixty days.

\section{Finality of orders}

Every order of the Refugee Appellate Authority shall be final.

\section{Rules and Regulations}

The Government may adopt such rulings as are required or are necessary or expedient to give effect to the provision of this Act.

20. Document DOHA/95/3 contains a "Proposed legal framework for the establishment of a safety zone for displaced persons in their country of origin", formulated by the Secretariat on the basis of the Thirteen Principles adopted by the Committee at its Twenty-eighth Session held at Nairobi in 1989 (reproduced in 3 AsYIL at pp. 265-6). The text of the "Proposed legal framework", the commentary which precedes it, and a table of examples of safety zones established by the United Nations, are reproduced below.

\section{Introduction}

People have been uprooted by persecution, conflict and famine in all ages. What is unique at the present time is the massive scale of such movements. 
The world's refugee population is estimated to be 17 million, [footnote: E\CN.4\1992\23, para 5] while the displaced people, largely women and children, who abandon their homes in search of food and water. Armed conflict, forced relocation. communal violence, natural and ecological disasters, systematic violation of human rights, as well as traditionally recognized sources of persecution combine to produce these massive involuntary movements within and outside state borders. There is nothing to suggest that this trend will be reversed in the immediate future.

9. The problems faced by internally displaced persons are to be seen in the larger context of the post-cold war period in which long suppressed ethnic and religious conflicts have been unleashed in many parts of the world. At the same time, there is a greater willingness on the part of the international community to address these problems and to try and develop for internally displaced persons standards and mechanisms comparable to those that assist and protect refugees. [footnote: There is adequate legal protection provided to refugees by virtue of the 1951 Convention and the 1967 Protocol, the 1959 OAU Convention, the 1984 Cartagena Declaration as well as the 1966 Bangkok Principles]

10. The crisis of internally displaced persons from the perspective of the international community is that they fall within domestic jurisdiction and are, therefore, not covered by the protection normally accorded to those who cross international borders and become refugees. International responses to emergencies involving them have been taken up by agencies like UNHCR, UNICEF or the ICRC, but in the absence of a clear mandate and an international body with special responsibilities for the protection of the internally displaced, the international response has been ad hoc in the appointment by the Secretary-General in 1991 of an Emergency Relief Coordinator to improve the provision of relief and assistance to those caught up in humanitarian emergencies. [footnote: In 1991, the Commission on Human Rights addressed the protection dimension of internal displacement (Res 1991 25).]

11. Principles of existing law: Human rights and humanitarian law may be seen as the principal sources of existing protection for internally displaced persons; along with refugee law, they also may be the foundation for articulating a basis for further protection. While these bodies of law are conceptually distinct, they have influenced and informed each other and also contributed to a general corpus of laws capable of application to the problems experienced by the internally displaced.

12. Unlike refugee law, which largely applies only when a border is crossed, or humanitarian law, which applies to situations of armed conflict, human rights law proclaims broad guarantees for fundamental rights of all human 
beings. The International Bill of Human Rights, composed of (a) Universal Declaration of Human Rights; (b) International Covenant of Economic, Social and Cultural Rights; and (c) International Covenant on Civil and Political Rights, represents the basic body of human rights law, recognizes the inherent dignity and equality of all human beings and sets a standard for achievement of their rights. Although human rights law provides a basis for protection and assistance for internally displaced persons, it does not directly address some of the situations affecting the internally displaced, such as forcible displacement and access to humanitarian assistance.

13. Since the UN has established protected areas of Safe Zones in time of armed conflicts such as in Cambodia, Bosnia, Rwanda, Somalia, the AALCC's study on the question has concentrated on the legal concept of a Safety Zone for internally displaced persons in armed conflict and on formulating basic principles. The Committee has been focusing on legal aspects of the following issues:

1. The circumstances under which a Safety Zone could be established.

2. Whether international organizations should be entrusted with the responsibility of the management of a Safety Zone?

3. The status of the Safety Zone.

\section{The formulation of a legal framework for the establishment of a}

Safety Zone for displaced persons

The AALCC in co-operation with the UNHCR has formulated "A Legal Framework for the Establishment of a Safety Zone for Displaced Persons in their country of origin" in order to incorporate basic principles agreed upon in international humanitarian laws and the decisions of international organizations. As is shown in the attached document, the framework is divided in seven parts, namely (1) the aim of establishing a Safety Zone; (2) conditions of establishment; (3) supervision and management; (4) duties of the Government and the conflicting parties concerned; (5) rights and duties of the displaced persons in a safety zone; (6) protection of the officials of the international organizations who manage the safety zone; (7) closure of the safety zone.

\section{The legal aspects of these issues}

The answers to some aspects of the three issues raised by the Committee are found in the framework.

(1) The circumstances under which a Safety Zone could be established.

A Safety Zone shall be established only when a considerable number of displaced persons arises as a result of armed conflicts or civil wars, and when their life and property are threatened as a consequence. Mass voluntary exodus or forced displacement of tens of thousands of people from their places of residence will be necessary conditions for the establishment of a Safety Zone. 
The Safety Zone shall be established only by the decision of the Security Council of the United Nations with the consent of the Government concerned and of the parties to the conflict. The Security Council must judge the conflict as a threat to the peace or a mass violation of human rights. Both the Government and the conflicting party should regard the measures as taken for the protection of the life and property of the civilians by international organizations. They must admit those actions as being neutral in character. The establishment of a Safety Zone is a form of humanitarian measure by the UN. The action will not violate the sovereignty of the state concerned. It will not affect nor threaten the territorial integrity of the State.

(2) Whether neutral bodies like International Organizations should be entrusted with the responsibility for the management of the Safety Zone? The Safety Zone should be placed under the supervision of the UN as it is established by the decision of the Security Council. The Security Council should designate an international organization to manage the Safety Zone. The designated international organization like UNHCR or ICRC should be responsible for the supply of shelter, food, medical care and other essential items of basic civic amenities for internally displaced persons. It will cooperate with other international organizations like WFO, WFP, WHO, UNICEF etc. and Member States for the implementation of its work.

The Safety Zone should be protected by security forces to keep off armed attacks by the conflicting parties. The arrangement must be done by the Security Council.

\section{The Status of the Safety Zone}

The Safety Zone should be an integral part of the country. However, due to armed conflicts, actual administrative power of the state is restricted and must be supplemented by management by a designated international organization.

The area surrounding a Safety Zone should be demilitarized. The armed forces of both conflicting parties should be withdrawn from the area so that the Safety Zone should be immune from hostile activities.

16. Proposed Legal Framework for the Establishment of a Safety Zone for Displaced Persons in their Country of Origin

1. The aim of establishing a Safety Zone

(1) to protect the life and property of displaced persons in their country of origin from consequences of armed conflicts, by placing them in a UN protected area;

(2) to prevent the exodus of refugees to neighbouring countries;

(3) to realize the principle of 'burden-sharing' in the assistance of displaced persons; 
(4) to develop the ideas of the Geneva Convention for the Protection of War Victims (1949) and the Protocol (1977).

2. Conditions

(1) The Safety Zone shall be established when a considerable number of displaced persons arises as a result of armed conflicts or civil wars, and their lives and property are threatened as a consequence.

(2) The Safety Zone shall be established by decision of the Security Council of the United Nations with the consent of the Government concerned and of the parties to the conflict.

(3) An agreement should be signed between the UN and the Government concerned, or among the UN and conflicting parties in case of the lack of unified government, to secure a specified geographical area for the Safety Zone.

(4) The area should be demilitarized and be immune from hostile activities. The armed forces of the State and the conflicting parties should be withdrawn from the area.

(5) The establishment of the Safety Zone should not violate the sovereignty of the State concerned. It should not threaten the territorial integrity of the State.

3. Supervision and the management

(1) The Safety Zone should be placed under the supervision of the UN.

(2) The Security Council will designate an international organization to manage the Safety Zone.

(3) An UN designated international organization should be responsible for the supply of shelter, food, medical care and other essential items of basic civic amenities for the displaced persons. It will co-operate with other international organizations and Member States for the implementation of its work.

(4) The UN may provide a multinational security force, if necessary and practicable, for the protection of the displaced persons in the Safety Zone.

(5) The cost of the maintenance of the Safety Zone should be met by voluntary contributions of:
a. Member States of the UN;
b. UN Agencies;
c. Inter-Governmental and Non-Governmental Organizations.

4. Duties of the Government and the conflicting parties concerned

(1) The Government of the State and the conflicting parties should have the duty to co-operate with the competent international organizations to establish and to manage the Safety Zone. 
(2) The lives and property of displaced persons should be guaranteed and be strictly protected by the Government and of the conflicting parties concerned.

\section{Rights and Duties of Displaced Persons}

(1) The right of displaced persons to receive fair and just treatment by the officials who supervise and manage the Safety Zone should be respected.

(2) The rights and duties of displaced persons in the Safety Zone should, as far as practicable and possible, be in accordance with those of a national of the State.

\section{Protection of the officials of International Organizations}

The Safety and Security of the officials of the international organizations engaged in supervising and managing the Safety Zone should be guaranteed by both the Government of the State and the conflicting parties.

\section{Closure of the Safety Zone}

The establishment of a Safety Zone should be of a temporary nature, and the Zone should be closed by the decision of the Security Council. In case of closure all the displaced persons should be returned safely to their permanent places of residence.

Some Examples of the Establishment of a 'Safety Zone' by the UN in armed conflicts

\begin{tabular}{|l|l|l|l|l|l|l|}
\hline Country & Year & $\begin{array}{l}\text { Name of } \\
\text { the pro- } \\
\text { tected } \\
\text { zone }\end{array}$ & Location & $\begin{array}{l}\text { Manage- } \\
\text { ment }\end{array}$ & $\begin{array}{l}\text { Strength } \\
\text { of mili- } \\
\text { tary } \\
\text { forces } \\
\text { involved }\end{array}$ & Remarks \\
\hline Cambodia & 1992 & $\begin{array}{l}\text { UN Pro- } \\
\text { tected } \\
\text { Area }\end{array}$ & $\begin{array}{l}\text { West of } \\
\text { the coun- } \\
\text { try }\end{array}$ & $\begin{array}{l}\text { UN Transi- } \\
\text { tional } \\
\text { Authority } \\
\text { in Cambo- } \\
\text { dia }\end{array}$ & 22,000 & $\begin{array}{l}\text { To promote } \\
\text { repatriation } \\
\text { and resettle- } \\
\text { ment of refu- } \\
\text { gees and dis- } \\
\text { placed persons }\end{array}$ \\
\hline $\begin{array}{l}\text { Bosnia \& } \\
\text { Herzegovina }\end{array}$ & 1992 & Safe Area & $\begin{array}{l}\text { Sarajewo, } \\
\text { Srebrenica } \\
\text { and four } \\
\text { other } \\
\text { cities }\end{array}$ & $\begin{array}{l}\text { UN Protec- } \\
\text { tion Force, } \\
\text { NATO } \\
\text { Forces also } \\
\text { involved }\end{array}$ & $\begin{array}{l}24,000 \\
\text { Ro protect Safe } \\
\text { Areas and } \\
\text { Activities of } \\
\text { the UNHCR }\end{array}$ \\
\hline Rwanda & 1994 & $\begin{array}{l}\text { Protected } \\
\text { Zone }\end{array}$ & $\begin{array}{l}\text { South- } \\
\text { West of } \\
\text { the coun- } \\
\text { try }\end{array}$ & $\begin{array}{l}\text { France, } \\
\text { afterward } \\
\text { UN }\end{array}$ & 1,400 & $\begin{array}{l}\text { To accommo- } \\
\text { date mainly } \\
\text { displaced per- } \\
\text { sons who lost } \\
\text { government } \\
\text { protection }\end{array}$ \\
\hline
\end{tabular}


21. Introducing the item, the Deputy Secretary-General, outlined the history of the Committee's consideration of the topics under discussion and the main elements in the two documents before the Committee. He invited Member Governments to examine the documents and communicate their views to the Secretariat.

\section{The Representative of the United Nations High Commissioner for Refugees} (UNHCR) observed that, of the present refugee population of some 24 million, the overwhelming majority were found in the territories of the Member States of AALCC. The majority of the world's internally displaced persons were also to be found in those countries. It was therefore imperative for the countries of the region to continue to develop a common approach to the humanitarian problems of such persons. Observing that the countries of the region differed in domestic norms and legal traditions in regard to refugees, making it virtually impossible to produce a single text of refugee protection legislation acceptable to all countries, he said he favoured the development of 'model' legislation for the purpose, which could be adapted to specific domestic or regional legal systems or concerns. Noting that, while some Members of AALCC were parties to the 1951 Convention on the Status of Refugees, others, mostly from Asia were not, he proposed the formation of a Working Group composed of the AALCC Secretariat, the office of UNHCR and representatives of the Member States of AALCC, including both States that were parties to the 1951 Convention and those that were not.

23. The President said that it was the responsibility of the international community to deal appropriately with the growing problems of refugees and internally displaced persons. In his opinion those problems should not be dealt with ad hoc, but on the basis of an international convention. He suggested that the further steps needed on the legal aspects could be discussed within the proposed Working Group.

24. The delegate of Egypt said that in his opinion the codification of legal norms in connection with safety zones was premature, since there did not appear to be a common legal content in practices relating to them. For the time being, the idea should be "to bring safety to people, rather than people to safety". As a first step, there should be a comprehensive study of the reasons and origins of conflicts, including their deep cultural dimensions. AALCC could undertake such a study, concentrating on regional aspects, and seeking collaboration with regional organizations which were well equipped to deal with the problems. Meanwhile, UNHCR, the International Committee of the Red Cross (ICRC) and non-governmental organizations should work out 
operational guidelines based on past practices which took into account the particular characteristics of each conflict, working therefore at the functional, rather than the legal level.

25. The delegate of Uganda proposed that the Committee go into the topic of refugees more deeply, and attempt to address fundamental questions such as the causes of refugee flows. Model legislation was, in his view, a temporary measure. What was needed was that African and Asian States should develop what he termed a "culture of accommodation and reconciliation".

26. The delegate of China said that the model legislation presented by the Secretariat would provide a suitable basis for the enactment of domestic legislation for AALCC Member States, and would be an appropriate supplement to the 1951 Refugees Convention and its 1967 Protocol. The provisions of the model legislation seemed to reflect the position and practice of the majority of Asian and African States, and their incorporation into national laws would exert a positive influence for the solution of issues concerning refugees among those States. As to the issue of the establishment of safety zones for displaced persons in their country of origin, it raised questions not merely of the legal status of such zones, but also problems connected with the jurisdiction and sovereignty of that country. Accordingly, in his view, this topic would need more profound and cautious study. Greater emphasis should be placed on resolving problems related to refugees. $\mathrm{He}$ believed that permissible, timely and effective measures should be taken to facilitate the return of refugees to their country of origin, in safety and dignity.

27. The delegate of Ghana found that the proposal for model legislation on the status and treatment of refugees was complementary to that concerning the establishment of safety zones for displaced persons in their countries of origin. As to the latter topic many problems remained unresolved, including conditions for the establishment of safety zones, and implications regarding the sovereignty of the State concerned, and urged that work on it should continue.

28. The delegate of Iran found that many concerns of Asian and African countries regarding the problems of refugees had been taken into account in preparation of the Secretariat draft model legislation, which he found commendable.

29. The delegate of Sudan said that in studying safety zones, careful consideration should be given to whose consent was needed as a condition for the establishment of such a zone, especially where a decision by the Security 
Council would have to be invoked. He would prefer it if any such Security Council decision were to be invoked after consultation among the parties concerned.

30. The delegate of Japan considered it essential that States become parties to the 1951 Convention relating to the Status of Refugees, and its 1967 Protocol, and take appropriate domestic legislative measures to implement those agreements. In his view, the draft model legislation would be more helpful if it included more detailed provisions concerning refugee recognition procedures. He said that the comparatively wide definition of the term 'refugee' in the Secretariat draft might not be realistic, as it might lead to additional burdens for neighbouring countries which provided protection and assistance to refugees, along with UNHCR. As to safety zones, he observed that although the proposed legal framework envisaged that establishment of a safety zone was subject to the consent and co-operation of the government, and of the conflicting parties, such consent would not be easy to obtain. Further study was required of the establishment of a safety zone without the consent of the government and the conflicting parties concerned. Account should be taken of the difficulties arising from the establishment of the safety zone controlled and supervised by foreign authorities in the territory of a sovereign State.

31. The delegate of Jordan said that, in his view, AALCC should support the Arab stand concerning resolving the problems of refugees, displaced persons and deportees. The delegate of India said that, as each State was faced by special problems concerning refugees, not one model of legislation could provide answers for all of them. The Secretariat's draft was before the Committee, and it was for governments now to give their preliminary views concerning it. No purpose would be served by submitting the draft to a Working Group at this stage. As to the concept of safety zones, he declared that it had neither legal sanction nor moral appeal. The delegate of Sri Lanka emphasized that the creation of a safety zone had to be subject to the consent of the State in whose territory the activity was being carried out, and could not be imposed on that State. In his view, dealing with internally displaced persons was within the mandates of UNHCR and ICRC. What was needed was additional funding for those organizations so as to make their initiatives more effective, not new mechanisms.

32. The delegate of Syria said that the item "Status and treatment of refugees" had always been distinct from the item "Deportation of Palestinians in violation of international law", and that the Committee should continue to deal 
with the items separately. The President confirmed that the two subjects were distinct from each other, and would be dealt with separately.

\section{Decision}

33. In the decision (Report, pp. 98-9) which followed discussion of the item (Report, pp. 64-74), the Committee, inter alia: “. . .

1. APPEALS to Member States to take all possible measures to eradicate the causes and conditions which force people to leave their countries and cause them to suffer unbounded misery;

2. URGES Member States who have not already done so to ratify or accede to the Convention relating to the Status of Refugees, 1951 and the 1967 Protocol thereto;

3. COMMENDS the Secretariat for having prepared the Model Legislation on the Status and Treatment of Refugees in co-operation with the Office of the UNHCR.

4. Also COMMENDS the Secretariat for revising the Nairobi Principles of 1989 and for formulating the "Legal Framework for the Establishment of a Safety Zone for Displaced Persons in their Country of Origin".

5. REQUESTS the Member Governments to send in their observations and comments on (i) the questionnaire sent by the Secretary-General in March 1994 and (ii) Model Legislation set out in Doc. No. AALCC/XXXIV/Doha/95 2;

6. ALSO REQUESTS the Member Governments to send their comments and observations on the proposed Legal Framework for the Establishment of Safety Zone for Displaced Persons in their Country of origin prepared by the Secretariat;

7. DIRECTS the Secretariat to study further the concept of Safety Zone in light of the comments received; 


\subsection{Law of international rivers}

34. The Committee had before it a document entitled "Law of International Rivers" prepared by the Secretariat (Doc. No. AALCC/XXXIV/DOHA/95/4) containing a brief history of the Committee's consideration of the item (on which see 4 AsYIL p. 354), as well as a summary of the work of the International Law Commission at its Forty-sixth Session on the topic "The law of the non-navigational uses of international watercourses" (including draft articles adopted on a second reading), and the resolution adopted by the Sixth (Legal) Committee of the General Assembly at its Forty-ninth Session in 1994.

35. The delegate of Bangladesh said that the upstream withdrawal of water from the Ganges, which was an international river, at Farakka, in total disregard of the fundamental and ancient rights of the lower riparian State, had not only adversely affected his country's climate, flora and fauna but also the lives of over 40 million of its nationals, particularly in the northern region. He also noted his country's efforts toward a regional approach to solution of the problem, and stressed that there was an urgent need for appropriate rules of international law on international rivers which would protect the rights of countries placed in a position similar to Bangladesh. He emphasized that the issue was of crucial importance to his country, and urged AALCC to address it.

36. The delegate of Pakistan said that his country, as a lower riparian State shared the concerns expressed by the delegate of Bangladesh, and supported his views on the item under discussion.

37. In the decision adopted (Report, p. 100) following discussion of the item (Report, pp. 39, 47, 57), the Committee, inter alia:

“. . .

2. COMMENDS the adoption of the draft articles on the Non-Navigational uses of International Watercourses as adopted by the International Law Commission on second reading;

3. URGES the Member States to consider utilizing the Secretariat studies and commentaries while furnishing comments on the draft articles before July 1996 to the United Nations;

4. REQUESTS the United Nations General Assembly to consider adopting a Convention on the Law of the Non-Navigational Uses of International Water- 
courses on the basis of the draft article adopted by the International Law

Commission and the comment made thereon by the Member States;

. .

\subsection{Law of the sea}

38. The Committee had before it two documents prepared by the Secretariat: "Law of the Sea: Report of the Secretary-General" (Doc. No. AALCC/ XXXIV/DOHA/95/5); and "Law of the Sea: Report on the work of the Assembly of the International Seabed Authority during the second part of its First Session held in Kingston, Jamaica, 27 February-17 March 1995" (Doc. NO. AALCC/XXXIV/DOHA/95/5A).

39. Document No. DOHA/95/5 contains a summary of the provisions of the Agreement relating to the Implementation of Part XI of the United Nations Convention on the Law of the Sea, adopted on 29 July 1994 (UN doc. A/48/ L.60 and add. 1), and in parts IV and V of the Report, concise descriptions of the work of the final session of the Preparatory Commission (August, 1994), and the first part of the First Session of the Assembly of the International Seabed Authority convened by the Secretary-General of the United Nations in accordance with paragraph 3 of article 308 of the UN Convention on the Law of the Sea, on 16 November 1994 to coincide with the entry into force of the Convention; as well as decisions taken at the ad hoc Meeting of States Parties to the UN Convention on the Law of the Sea on 22 November 1994. Parts IV and $\mathrm{V}$ of the document are reproduced below.

Law of the Sea: report of the Secretary-General (AALCC)

“. .

\section{Meeting of the International Seabed Authority}

43. The final session of the PREPCOM was held in New York in August 1994. The PREPCOM had two substantive items in its agenda, viz. the implementation of Resolution II of UNCLOS and had then considered matters arising from the imminent entry into force of the United Nations Convention on the Law of the Sea. On the question of implementation of Resolution II of the UNCLOS the PREPCOM, inter alia, considered (i) the relinquishment of pioneer areas; (ii) compliance with understanding on the fulfilment of 
obligations by the registered pioneer investor, Inter-Oceanmetal Organization (IOM) and its certifying States; (iii) waiver of the annual fixed fee and the obligation of the three registered pioneer investors and of their certifying States to carry out stage I of the exploration work; and (iv) report of the Group of Technical Experts to the General Committee on the application of the Government of the Republic of Korea for registration as a pioneer investor.

44. On matters arising from the imminent entry into force of the Convention the issues before the PREPCOM included (i) consideration of the provisional agenda for the first session of the Assembly and of the Council of the Authority; (ii) consideration of the budget for the first financial period of the International Seabed Authority; (iii) date of the first session of the Assembly of the Authority; (iv) proposed meeting of the States parties to the Convention relating to the practical arrangements for the establishment of the International Tribunal for the Law of the Sea; and (v) final report of the PREPCOM to the Assembly of the International Seabed Authority at its first session.

45. It may be recalled that paragraph 3 of Article 308 of the Convention on the Law of the Sea provides that the Assembly of the Authority shall meet on the date of entry into force of the Convention and shall elect the Council of the Authority, which is the executive organ of the Authority comprising 36 members. Accordingly, the Secretary-General of the United Nations, H.E. Mr. Boutros-Boutros Ghali, opened the first session of the International Seabed Authority in Kingston on 16 November 1994 to coincide with the coming into force of the Convention. The three-day session which was largely ceremonial in nature decided to convene a resumed session between 27 February and 17 March 1995.

V. Ad hoc meetings of States Parties to the United Nations Convention on the Law of the Sea

46. On the question of establishment of the International Tribunal for the Law of the Sea the PREPCOM at its session held in August 1994 had recommended that the Secretary-General convene an ad hoc meeting of the States Parties to the Convention soon after the entry into force of the Convention. Following this recommendation of the PREPCOM relating to the establishment of the International Tribunal an ad hoc meeting of States Parties to the Convention on the Law of the Sea was convened in New York in November 1994. That meeting of the States Parties to the Convention decided on 22 November 1994 inter alia that: (i) there will be a deferment of the first election of the members of the Tribunal. The date of the first election of the 
members will be 1 August 1996. This will be a one-time deferment; (ii) nominations would open on 16 May 1995. A State in the process of becoming a party to the Convention may nominate candidates. Such nominations shall remain provisional and shall not be included in the list to be circulated by the Secretary-General of the United Nations in accordance with Article 4(2) of Annex VI, unless the State concerned has deposited its instrument of ratification or accession before 1 July 1996; (iii) nominations will close on 17 June 1996; (iv) the list of the candidates will be circulated by the SecretaryGeneral on 5 July 1996; (v) subject to the above decisions all procedures relating to the election of the members of the Tribunal as provided for in the Convention shall apply; and (vi) no changes shall be made to this schedule unless the States Parties agree by consensus."

40. Document DOHA/95/5A, describes the second part of the First Session of the Assembly of the International Seabed Authority (Kingston, 27 February - 17 March 1995), during which difficult questions concerning the composition of the Council were addressed. The document is reproduced below in its entirety.

REPORT OF THE WORK OF THE ASSEMBLY OF THE INTERNATIONAL SEABED AUTHORITY DURING THE SECOND PART OF ITS FIRST SESSION HELD IN KINGSTON, JAMAICA, 27 FEBRUARY - 17 MARCH 1995

1. The second part of the first session of the Assembly of the International Seabed Authority was convened in Kingston, Jamaica, from 27 February to 17 March 1995. The first part, which was primarily of a ceremonial nature, had earlier been held in Kingston from 16 to 18 November 1994 to commemorate the establishment of the International Seabed Authority, which coincided with the entry into force of the United Nations Convention on the Law of the Sea. The third part of the first session is scheduled to be held in Kingston from 7 to 18 August 1995.

The Assembly was attended by delegates from 87 Member States and one entity, the European Community. 15 States and 5 International Organizations took part in the Sessions as Observers and the AALCC was represented by the Assistant Secretary General, Mr. AsGHAR DASTMALCHI.

2. Mr. HANS CORELL, Under-Secretary-General for Legal Affairs and Legal Counsel of the United Nations, acting as the Temporary President of the Assembly, opened the second part of the first session. During the initial meeting the Assembly decided to commence its work under the draft rules of 
procedure recommended by the preparatory Commission for the International Seabed Authority and for the International Tribunal for the Law of the Sea until such time as it adopted its own rules of procedure.

The Assembly had on its agenda the election of the President, the adoption of its rules or procedure, election of members of the Council of the Authority, the nomination and election of the Secretary-General of Authority and election of members of its other major organs (the Legal and Technical Committee and the Finance Committee). Consideration of the final report of the preparatory Commission for the International Seabed Authority and for the International Tribunal for the Law of the Sea, the organization of a Secretary, a provisional budget and other financial matters, and the transfer of property and records from the Preparatory Commission to the Authority were also on the agenda of the meeting.

3. The Assembly elected by acclamation, Dr. HASJM DJALAL (Indonesia) as President of its first session. He had served as Chairman of the Special Commission of the Preparatory Commission and had been actively involved in several aspects of negotiations of the Convention on the Law of the Sea. Mr. DJALAL also served recently as Chairman of the 'Group of 77' developing countries.

On the election of Vice-Presidents for the Assembly, discussions took place on whether regional groups as well as special interest groups should be represented on the Bureau of the Assembly. While some believed that burdening the Assembly with a large Bureau representing regional and special interests would detract from its efficiency, a few speakers said that the special interest groups recognized by the Convention on the Law of the Sea must be represented. Finally, four Vice-Presidents - Algeria, Mexico, Russian Federation and Canada - were elected by acclamation from the list of candidates drawn up by the President of the Assembly after consultations with regional Groups. The four Vice-Presidents represent all the regional groups except Asia, which holds the presidency.

4. The Assembly, following informal consultations held by the President, appointed the following 10 members to a Working Group assigned to develop the Assembly's rules of procedure: Egypt (Chairman), Germany, United Kingdom, Russian Federation, Poland, Brazil, Jamaica, Republic of Korea, Indonesia and Senegal.

The Preparatory Commission for the International Seabed Authority and for the International Tribunal for the Law of the Sea had recommended to the Assembly for its consideration draft rules of procedure contained in document LOS/PCN/WP20/Rev.3. In addition, and in the light of the adoption by the United Nations General Assembly on 28 July 1994 of the Agreement relating to the Implementation of Part XI of the United Nations Convention on the Law of the Sea, the Secretariat had prepared document ISBA A WP.1 containing 
suggestions for revising the draft rules of procedure of the Assembly issued by the Preparatory Commission taking into account the provisions of the Agreement. At the request of the Assembly, the Secretariat then prepared a working paper by merging these two documents, and the new document (ISBA/A/WP.2) was then considered by the Working Group. Following discussions, the working group submitted to the Assembly an updated version of the draft rules of procedure (document ASBA/A/WP.3).

5. According to the draft rules of procedure the Assembly shall meet in regular annual sessions, unless it decides otherwise (rule 1). Provisions also exist for the holding of special sessions, with an advance notice of at least 30 days (rule 4). Meetings shall be held at the seat of the Authority, unless the Assembly chooses otherwise (rule 5). At the beginning of each session the Assembly shall appoint a nine-member Credentials Committee and elect a President and four Vice-Presidents in a way that would ensure the representative character of the Bureau (rules 24, 28). The Bureau shall meet periodically throughout the session to review the process in the Assembly's work and make recommendations (rule 35).

Regarding the Secretariat of the Authority, which will be headed by the Secretary-General, the draft provides that it would receive, translate, reproduce and distribute documents, reports and resolutions of the Assembly and its subsidiary organs and generally perform all other work required by the Assembly (rule 17).

The meetings of the Assembly will be held in public, unless the Assembly decides that exceptional circumstances require that the meeting be held in private (rule 43). As a general rule, meetings of the subsidiary organs shall be held in private. The President may declare a meeting open when at least a majority of the members of the Assembly are present (rule 45).

Each member of the Assembly shall have one vote, and participation in decision-making by inter-governmental organizations shall be in accordance with Annex IX of the Convention of the Law of the Sea (rule 60). As a general rule, decision-making should be by consensus (rule 61). However, if all efforts to reach consensus fail, decision on procedural questions shall be taken by a majority of members present and voting, provided that such a majority includes a majority of the members participating in the session.

The Assembly's decisions on matters within the Council's competence shall be based on the latter's recommendations. The Assembly shall take financial and budgetary decisions based on the Finance Committee's recommendations (rule 61).

The draft provides that all elections will be held by secret ballot (rule 72). When a person or member of the Assembly is to be elected and no candidate obtains, in the first ballot, the votes of a majority of the members of the Assembly present and voting, a second ballot restricted to the two candidates 
receiving the largest number of votes shall be taken (rule 73). If in the second ballot the votes are equally divided, the President shall decide between the candidates by drawing lots. The rules also provide guidelines for other voting scenarios.

Concerning the establishment and composition of subsidiary organs, the rules state that account shall be taken of the principle of equitable geographical distribution and of special interests and the need for members to be qualified and competent in the relevant technical questions dealt with by those organs (rule 77). Any Assembly member not a member of a subsidiary organ shall have the right to explain its views to that organ when a matter affecting that member is being discussed (rule 78).

Regarding the suspension of voting rights, any member of the Assembly in arrears in the payment of financial contributions to the Authority shall have no vote if the amount owed equals or exceeds its assessed contributions for the preceding two years (rule 80 ). The Assembly may permit those members to vote if it is satisfied that the failure to pay is due to conditions beyond the member's control.

Members of the Authority which have been found by the Seabed Disputes Chamber of the International Tribunal for the Law of the Sea, to have 'grossly and persistently' violated the provisions of part XI of the Convention (which deals with the seabed mining regime) may be suspended from the exercise of the rights and privileges of membership by the Assembly upon the recommendation of the Council (rule 81).

The rules stated that the following may participate as observers in the Assembly: Sates and entities referred to in Article 305 of the Convention which are not members of the Authority; national liberation movements which in their respective regions are recognized by the Organization of African Unity or the League of Arab States; observers to the Third United Nations Conference on the Law of the Sea who signed the Final Act of the Conference and are not referred to in article 305; the United Nations and its specialized agencies; the International Atomic Energy Assembly; and non-governmental organizations with which the Secretary-General has entered into arrangements or which have been invited by the Assembly (rule 82). Observers are not entitled to participate in the taking of decisions.

Regarding the composition of the 36-member Council, the rules reproduce the five categories of membership outlined in paragraph 15 of the annex to the Agreement relating to the Implementation of Part XI of the Convention (rule 84).

Before electing the members of the Council, the Assembly shall establish lists of countries fulfilling the criteria for membership in each category (rule 83). States fulfilling criteria in more than one category will be included in all relevant groups, but may only be proposed for election by one group and shall represent only that group in voting. Each group shall nominate only as many 
candidates as the number of seats. The principle of rotation shall apply. as a general rule, when the number of candidates exceeds the number of seats.

The rules state that the Secretary-General of the Authority shall be elected for four years by the Assembly from among candidates proposed by the Council; he may be re-elected (rule 88). The Assembly, on the recommendation of the Council, shall elect the 15 members of the Governing Board of the enterprise - the seabed mining arm of the Authority (rule 89). The DirectorGeneral of the Enterprise shall be elected by the Assembly, upon the recommendation of the Council and the nomination of the Governing Board (rule 92). The Director-general, who will not be a member of that Board, shall hold office for a fixed term not exceeding five years, and may be re-elected.

Regarding administrative and budgetary questions, the rules of procedure state that the annual budget of the Authority shall be approved by the Assembly following its submission by the Council, taking into account the recommendations of the Finance Committee (rule 93). No resolution involving expenditure shall be recommended unless it is accompanied by an estimate of expenditures prepared by the Secretary-General and any recommendations of the Finance Committee (rule 94).

The Assembly shall assess the contributions of members of the Authority to the administrative budget in accordance with an agreed scale of assessments based upon the scale used for the regular budget of the United Nations, until the Authority shall have sufficient income from other sources to meet its administrative expenses (rule 95).

On the Finance Committee, the rules state that the Assembly shall elect 15 members to the Committee from candidates nominated by States Parties, taking into account equitable geographical representation and special interests (rule 96). The first four categories of Council members shall be represented on the Finance Committee by at least one member and until the Authority remains dependent on assessed contributions, the five largest contributors to the budget will also be represented on the Committee. Members of the Finance Committee will be elected for five-year terms.

6. The Assembly in the course of discussing the draft rules of procedure recognized the difficulties and lack of agreement on the provision or Rule 85 on the terms of office of some Council members, which calls for determining by lot which Council members will serve an initial two-year term. But finally the Assembly adopted the Rules of Procedure, and decided that the determination of the members of the Council whose terms were to expire at the end of two years, should as a general rule, be left to the agreement of each group. If no agreement could be reached, the members whose terms were to expire at the end of two years should be chosen by lot to be drawn by the President of the Assembly immediately after first election. 
7. The complexity of determining the criteria for membership in the various groups of States in the Council, caused great difficulties and consumed almost the entire time of the session. According to the Agreement relating to the Implementation of Part XI of the United Nations Convention on the Law of the Sea, the Council shall consist of 36 members from five groups of States.

Group I would have four members from among those parties which, during the last five years, have either consumed more that 2 per cent in value terms of total world consumption or have had net imports of more than 2 per cent in value terms of total world imports of the commodities produced from the categories of minerals for be derived from the international seabed area the 'Area'. Of those four, one should be the State with the largest economy in Eastern Europe in terms of gross domestic product on the date of the entry into force of the Convention.

Group II would have four members from among the eight parties which have made the largest investment in preparation for and in the conduct of activities in the Area.

Group III would consist of four State parties which, on the basis of production in areas under their jurisdiction, are major net exporters of the categories of minerals to be derived from the Area, including at least two developing States whose exports of such minerals have a substantial bearing upon their economies.

Group IV would have six members from among developing States, representing special interests. The special interests to be represented would include those States with large populations, land-locked or geographically disadvantaged States, island States, States which are major importers of the categories of minerals to be derived from the Area, States which are potential producers of such minerals and least developed States.

The last group, group $V$, would have 18 members elected on the basis of equitable geographical distribution, provided that each geographical region shall have at least one member elected. For this purpose, the geographical regions shall be Africa, Asia, Eastern Europe, Latin America and the Caribbean, and the Western Europe and Other States.

8. Different formulae and several criteria for membership in the Council were discussed in the Assembly. The President of the Assembly was asked to draw up a list of countries for applying for membership in the Council under specific interest categories defined by the Convention and the Agreement, to enable those States to start negotiating on nomination for the Council. As the number of potential candidates in each interest group exceeded the number of seats allotted for that group, so it seemed necessary that the principle of rotation, as mentioned in the Agreement, should be applied as a general rule. States in those groups should themselves determine how to apply the principle. There was no doubt that a State could be nominated from only one group, even if that State met the criteria for membership in more than one group. 
9. During the debate, it appeared that the question of equitable geographical distribution of seats in the Council would be problematic. Many speakers said that the Council should provide both for representation among interest groups and for equitable geographic distribution. As both are important, so it should be determined which countries fell into which categories, with countries specified for more that one category being listed in only one. It was argued by some developing countries that equitable geographical distribution must be an essential part of the final make-up of the Council. Out of the 36 members of the Council, the appropriate representation for each regional group had to be determined. To some degree the allocation in Group I(a), II(b) and III(c) would affect membership in Group IV(d) and V(e).

10. In determining the appropriate representation in the Council there were divergent views, whether distribution of Council seats among the regional groups should be in proportion to their membership in the Assembly of the Authority or other criteria including the 'so-called North-South balance', the principle of fairness and flexibility to be considered economic weightage in determining seat allocations which reflected the financial contributions of States to the Authority, the seriousness of a member's candidacy and the idea that distribution of seats should be forward-looking with no reference to past formulae, were discussed extensively.

11. The representative of Sudan proposed that by dividing the number of members in the Assembly 139 by the 36 Council seats, each Council seat would represent 3.86 Assembly members. By dividing the number of Member States in each region by that figure he calculated the following formula for proportional representation. Africa, which has 44 members, would have 11.39 seats; Asia with 38 members, should have 9.84 seats; Eastern Europe, with 13 member States, should have 3.76 seats; Latin America and the Caribbean with 23 members, should get 5.96 seats, and the Western European and other States, with 21 members, would get 5.44 seats. Several representatives of developing countries explained that the Convention and the Agreement relating to the Implementation of Part XI, provided clear guidance on how Council seats were to be allocated. The letter of those agreements should be adhered to. If the Assembly pursued the concept of 'weighted voting', it would be opening up a Pandora's box and, in effect, going backwards.

12. The industrialized countries of the West believed that the principle of equitable geographical representation on the Council should not be based on proportionality, in other words, simply the number of members in each group. Although their group was small, it included powerful consumer and producer interests that should be adequately reflected on the Council. So the need to seek a proper balance between industrialized countries on the one hand and developing countries, on the other, should be adhered to. The aim was that the 
majority of the South would not be in a position to automatically achieve a decision with a two-thirds majority, only to be vetoed in one of the chambers on the Council. The North-South "balance would also prevent a minority from constantly blocking decisions". Balance works both ways.

13. The representative of France speaking on behalf of the Western European and other States Group, said that he agreed that the Assembly must abide by the letter of the Agreement which spoke of equitable geographical distribution. His Group was not trying to go back in the Agreement, but the last category of members described in the Agreement dealt specifically with equitable geographical distribution. There was no case for equitable geographical distribution in the Council to be based solely on the number of States in each regional group. Proportionality was not the sole parameter for applying the criterion of equitable geographical distribution. Criteria other than numbers should be used. The councils of other international organs, such as the Food and Agriculture Organization (FAO), had strong powers; therefore, the Council of the International Seabed Authority would have a very important character. The Assembly should take a closer look at the positive arguments in favour of the two ideas of his Group. The first was the question of partnership in the exploitation of the deep seabed to ensure that products were extracted and distributed. Partners should be equal and the notion of blocs should not be emphasized excessively. If that were to be the case, then the industrialized countries, which were in a minority, would not be keen to accede to the Convention. If the industrialized group were relegated to a minority, they would be frustrated.

The Assembly should base its decisions on real, international, objective criteria. For example, in the United Nations Development Programme (UNDP) and the United Nations Children's Fund (UNICEF), the Western European States had the largest number of seats. Those were facts that had a meaning in the capitals of those States. The Western States would prefer to avoid the use of blocs and a North-South dichotomy. No party should be put in an uncomfortable, minority position.

14. Other representatives of the industrialized countries while endorsing the views put forward by France indicated that the composition of the Council should inspire confidence in those capitals where ratification of the Convention was still being considered. The application of equity in the present context required a political decision, taking into account a multitude of factors to achieve a balanced co-operation, not confrontation. It was mentioned that the Authority was not a political international organization like others, it was an economic body, dedicated to exploiting resources of the deep seabed. States such as the Western States should be able to bring to bear their economic weight in the work of the Authority. There was reference to other bodies in the United Nations system, in which proportionality had not been the basis for 
determining equitable geographical distribution. The UNDP and the UNICEF governing bodies had distributions that were consistent with the desire of the Western States, to ensure the positive engagement of the Industrialized Countries to develop the technology for the mining of the deep seabed. If those States failed to undertake the work, there would be no benefits to be shared.

In essence, it was mentioned, there were only two groups of States: those which undertook activities and those that did not do so. Partnership between both the groups was needed. The West had not put forward exaggerated proposals, because the Convention had made clear that there could be at least nine Council members from developed countries.

15. The developing countries, surprised by the new demands of the industrialized States, reminded them that the North was not in danger of being swamped in the Council, in a manner similar to that of the United Nations Conference on Trade and Development. In fact, many industrialized developing countries such as the Republic of Korea which were neither in the South nor in the North, were likely to be major operators in the International Seabed Area. There could not be a rigid dichotomy between two supposed categories of countries in respect of deep seabed mining. Many so-called developing countries were more industrialized than countries in Europe and they were in fact in a state of an 'in-betweenity'. Many speakers from 'the Group of 77' were of view that the Assembly should adhere to the clear formula dealing with the composition of the Council as contained in the Agreement and not consider the criteria for determining Council membership. It should work with the legal text before it, remembering that it was enacting legislation of a permanent nature. States that might lack the capability or technology today might develop those abilities in the future, and their interest should not be frustrated today.

16. The representative of Brazil proposed that the Assembly should try to evaluate the real interest of States and regions by assessing their presence at the current session, the very first of the International Seabed Authority. Based on the list of participants, there was a total of 75 States taking active part in the Assembly: 23 from Africa, 19 from Asia, 15 from Latin America and the Caribbean, 15 from Western European and other States, and 3 from Eastern Europe. That was a ratio of 2.08 Assembly members to each Council seat. Based on a division by 2.08, therefore, 11 Council seats should be allotted to Africa, 9 to Asia, 7 to Latin America and the Caribbean, 7 to Western Europe and other States, and 1 to Eastern Europe, for a total of 35 seats. The one seat outstanding in the Council could be allocated later.

17. Some developing countries recalled that they had made several concessions to ensure universal participation in the Convention by recognizing the interests 
of nations that had not ratified the Convention. Equitable geographical representation was necessary to secure co-operation by all sides. No group of States should be allowed to exercise hegemony over the Council. The comparison of the Authority with other international organizations was odious as the Authority was different from other bodies. The Council should not elevate the interests of some groups above those of others to such an extent that they would dominate the Council at the expense of those which had ratified the Convention. The Authority was to govern the Common Heritage of Mankind, which was why all interests must be kept in balance.

18. The President, after several lengthy discussions, proposed a formula for allocating the seats in the Council in respect of each regional group. His proposal took into account the concept of proportionality and the need to maintain a balance in the representation in the Council. The President made the following suggestion:

(a) The distribution of seats among the geographical regions for this election of the members of the Council shall be without prejudice to the distribution of seats among the geographical regions for the next election of the members of the Council, which shall have to take into account the new membership of the Authority at that time;

(b) Representation by a member in the present Council of a particular group of States referred to in paragraph 15(a) to (d) of section 3 of the Annex to the Agreement, whether or not the principle of rotation is applied in that Group, shall be without prejudice to its representing other groups of States in the future; at the same time, the representation by members in the present Council of the various groups of States does not preclude the rights of other States to represent these groups in the future.

(c) The general balance of seats established in the present Council between developing and developed countries shall be maintained in the future.

The President's proposal regarding the allocation of seats in the Council was discussed extensively in meetings of regional groups. Since no unanimous decision emerged from the discussions of the proposal it was not possible to reach consensus on this issue.

19. The meetings of the group of States referred to in paragraph 15(a) of the Agreement, "States parties which, during the last five years for which statistics are available, have either consumed more than 2 per cent in value terms of total world consumption or have had net imports of more than 2 per cent in value terms of total world imports of the commodities produced from the categories of minerals to be derived from the Area", known as Group A or group 1 were attended by Belgium, Brazil, China, France, Germany, Italy, Japan, Republic of Korea, Russian Federation, all be United Kingdom and United States (Coordinator). The Group met to discuss the nomination of four 
States meeting the criteria contained in that paragraph for election to the Council.

The Group decided not to recommend a list of States meeting the criteria of paragraph 15(a). Members of the Group held different views on the interpretation of the criteria. Some expressed the view that the criteria require that a consuming or importing State must meet the 2 per cent threshold for the value of each of the four minerals (manganese, copper, cobalt and nickel). Others expressed the view that the criteria require that States meet the threshold for the combined value of all four minerals. Without prejudice to the resolution of this question in regard to future elections, the Group decided to take a flexible and inclusive approach to its deliberations.

The Group took note of the fact that the United States, the United Kingdom, the Russian Federation, Japan, Germany, Belgium and Italy informed the President of the Assembly of their interest in being nominated for election to the Council. Belgium, Italy and Germany decided to withdraw their request to be nominated by the Group on the understanding that, without prejudice to the interests of other States meeting the criteria in paragraph 15(a), the application of the principle of rotation in future elections would provide opportunities for their election to the Council as representatives of the Group.

The Group agreed to the nomination of Japan, the Russian Federation, the United Kingdom and the United States. The Group agreed to nominate the Russian Federation and the United States for election for a two-year term and to nominate Japan and the United Kingdom for a four-year term. It should be noted that the acceptance by the Russian Federation and the United States of two-year terms is on the understanding that the Assembly will affirm, at the time of election, that paragraph 15(a) requires the inclusion of one State from the Eastern European region having the largest economy in that region in terms of gross domestic product and of the State, on the date of entry into force of the Convention, having the largest economy in terms of gross domestic product, should those States seek re-election to the Council under that paragraph, and upon the understanding that the principle of rotation would apply to Japan and the United Kingdom after four years.

20. After the initial meetings of the group of States referred to in paragraph 15(b), or Group II "which have made the largest investments in preparation for and in the conduct of activities in the Area, either directly or through their nationals", known as Group B or Group II, the coordinator of the Group, Canada, informed the President that after considering information provided by delegations with respect to investments by their States in preparation for and in the conduct of activities in the Area, the delegations unanimously agreed that the following States constitute the eight largest investors for purposes of paragraph 15(b): China, France, Germany (Coordinator), India, Japan, the Netherlands, Russian Federation and the United States. 
The Group of the eight largest investors proceeded to discuss the nomination of the four candidates to represent the Group in the Council. Five States, China, France, Germany, India and the Netherlands, declared their intention to represent the Group in the Council. In consultations between the interested States as well as between them and the coordinators it was not possible to reach agreement on which four States shall be nominated. It was also not possible to decide which of the candidates will be nominated to serve on the Council for a two-year term or for a four-year term. Also unresolved was the question of the application of the principle of rotation.

21. The meetings of the group of States referred to in paragraph 15(c), or Group III, "States parties which, on the basis of production in areas under their jurisdiction, are major net exporters of the categories of minerals to be derived from the Area", known as Group C, were attended by Australia (Coordinator), Brazil, Canada, China, Chile, Cuba, France, Gabon, India, Indonesia, Mauritania, Mexico, Namibia, Philippines, Poland, Russian Federation, South Africa, United States and Zambia.

Six countries from this Group - Australia, Chile, Gabon, Indonesia, Poland, and Zambia - presented their candidatures for the four seats available in this Group. Although some delegations have indicated a willingness to be flexible, at this stage - and particularly in the light of the fact that other issues still need to be resolved - there has been no final agreement on the four candidates.

It was also agreed that the principle of rotation should apply to future elections of candidates for the Group, and that this should be interpreted as meaning that there is a general expectation that members of this Group will move on and off the Council. This would not preclude the possibility of individual countries making informal arrangements between themselves, such as reciprocal support arrangements. Nor would it preclude countries having consecutive terms on the Council, if this was agreed by the Group.

It was further agreed that at this stage it was not appropriate to make a definitive list of countries eligible for election to the Group. However, some delegations suggested that this was something which should be considered in the future. Reference was made to an informal understanding reached at the Third United Nations Conference on the Law of the Sea that the Group should reflect an equal balance between developing and developed countries. But some delegations challenged it and questioned the logic and reason to maintain an equal balance between the North and the South in this group exclusively. The issue of which candidates would be nominated for a two-year term and which would be nominated for a four-year term was not discussed.

22. The meetings of the group of States referred to in paragraph 15(d), of the Agreement "developing States parties, shall represent special interests. The special interests to be represented shall include those States with large 
populations, States which are land-locked or geographically disadvantaged, island States, States which are major importers of the categories of minerals to be derived from the Area, States which are potential producers of such minerals and least developed States", known as Group D, were attended by Argentina, Bangladesh, Brazil, Burkina Faso, Cameroon, China, Costa Rica, Cuba, Egypt, Fiji, Gabon, India, Indonesia (Coordinator), Jamaica, Kuwait, Malaysia, Malta, Marshall Islands, Mauritania, Mexico, Mozambique, Myanmar, Nigeria, Oman, Paraguay, Philippines, Republic of Korea, Sudan, Trinidad and Tobago, United Arab Emirates, Viet Nam and Zambia. Several States declared their intention to seek nomination to the Council within this Group, and other States also expressed their interest in being nominated in either Group D or Group E. In view of the discussions taking place in other Groups, no definitive list of candidates of this croup has been drawn up.

23. The President, at the concluding meeting expressed the hope that during the third part of the first session of the International Seabed Authority which would be held in Kingston from to 18 August 1995 the matter of the election of the Council members would be resolved. Some delegates, however, could not conceal their dissatisfaction, as no business was accomplished, except the adoption of the Rules of Procedure".

41. Discussion of this item (Report, pp. 60-64) was followed by adoption of an essentially procedural decision (Report, pp. 101-102).

\subsection{Deportation of Palestinians in violation of international law, particularly the Geneva Convention of 1949 and the massive immigration and settlement of Jews in the occupied territories}

42. The Committee had before it a Report of the Secretary-General of AALCC bearing the title of the item (Doc. No. AALCC/XXXIV/DOHA/95/6), inter alia, outlining the evolution of the 'Middle East Peace Process', and inviting guidance from members as to the future work of the Secretariat, as follows:

“. . .

9. It may be recalled that on September 13, 1993 the PLO-Chairman YASSER ARAFAT and the Israeli Prime Minister H.E. Mr. ITZHAK RABIN had signed the Declaration of Principles on Interim Self-Government Arrangements. ffootnote: A/48/48-6-S/26560, Annex. Also in International Legal Materials, Vol. (1993) p. 1525.] The Agreement opened the way for Palestinian self-rule providing for Israel's withdrawal and the establishment of interim Palestinian self-government, first, in the Gaza Strip and in the West Bank town of 
Jericho, and later in the rest of the West Bank. The Declaration of Principles deferred the issue of Israeli settlements to the permanent status negotiations which are to begin no later than the beginning of the third year after the start of the interim period. In the meantime Israel retains legal and administrative authority over these settlements and their inhabitants and is responsible for their security. Under the terms of the Declaration of Principles on Interim Self-Government Arrangements the permanent status negotiations on the issue of Jerusalem are to start not later than the beginning of the third year of the interim period. Other sensitive issues such as the return of Palestinian refugees, future boundaries and the status of Palestine are envisaged for further negotiations which are to commence no later than two years after the Israeli withdrawal marks the beginning of a five year interim period at the end of which it is expected that the negotiations will lead to permanent settlement implementing Security Council Resolutions 242 (1969) and 338. It may be stated that the Committee at its Thirty-third Session inter alia welcomed the signing of the above mentioned accord of September 1993.

10. Thereafter on 4 May 1994 the Palestine Liberation Organization and the State of Israel signed an Agreement on the Gaza Strip and the Jericho Area. The accord, concluded in Cairo inter alia provided for Israel's withdrawal from the Gaza Strip and Jericho Area and granted Palestinians a measure of self-government. The accord of 4 May 1994 grants Palestinians control over their internal political arrangements and daily affairs including elections, tax collection and the adoption and enforcement of legislation. The Agreement marks the beginning of the five year interim period for negotiating a settlement of the permanent Status of the occupied territory. Since then a twenty four member Palestinian authority vested with legislative and executive power has been established. A Palestinian police force has also been established.

11. The Middle East Peace Conference convened at Madrid on 31 October 1991 and the mutual recognition between the State of Israel and the Palestine Liberation Organization, as the representatives of the Palestinian people was welcomed by the General Assembly by its resolution 46/58 when it expressed its full support for the "achievements of the peace process thus far, in particular the Declaration of Principles on Interim Self-Government Arrangements signed by Israel and the PLO and the Agreement between Israel and Jordan on the common Agenda. The General Assembly went on to term these developments an important initial step in achieving a comprehensive, just, and lasting peace in the Middle East and urged all parties to implement the agreements reached.

12. The General Assembly at its Forty-eighth Session in its resolution on the Peaceful Settlement of the Question of Palestine inter alia stressed the significance of upcoming negotiations for the final settlement and reaffirmed 
the following principles for the achievement of a final settlement and comprehensive peace:

(a) The realization of the legitimate national rights of the Palestinian people; primarily the right to self-determination;

(b) The withdrawal of Israel from Palestinian territory occupied since 1967, including Jerusalem, and from other occupied Arab territories;

(c) Guaranteeing arrangements for peace and security of all States in the region including those named in Resolution 181 (III) of 29 November 1947, within secure and internationally recognized boundaries;

(d) Resolving the problem of Palestinian refugees in conformity with the General Assembly resolution 194 (III) of 11 December 1948 and subsequent relevant resolutions;

(e) Resolving the problem of the Israeli Settlements which are illegal and an obstacle to peace, in conformity with relevant United Nations resolutions; and

(f) Guaranteeing freedom of access to Holy Places, religious buildings and sites. [footnote: See General Assembly Resolution 48/158-D on the Peaceful Settlement of the Question of Palestine.]

Similar resolutions were also adopted at the Forty-ninth Session of the General Assembly. [footnote: See General Assembly Resolutions 49/62-D of 14 December 1994 and 49/88 of 16 December 1994.]

13. It may be mentioned that the resolution entitled 'Middle East Peace Process' was sponsored by more than 100 States and received an unprecedented majority and that the resolution on intifadah which the General Assembly had adopted every year since its Forty-third Session (1988) was deferred.

14. Against this backdrop to the progress of work since the item was first placed on the work programme of the Secretariat, the recent developments and the resolution of the Committee at its Thirty-third Session, the Committee may wish to consider whether the Secretariat has exhaustively dealt with the Legal Aspects of the item referred to it and determine the course of future work of the Secretariat on the matter.

43. The Committee, having heard statements by, inter alia, the delegate of Palestine, the Deputy Secretary-General and the delegate of Syria (Report, pp. 70, 71-2, and 73) adopted, after accepting amendments proposed by Sudan and Japan, a decision directing the Secretariat "to continue to monitor the developments in the occupied territories from the viewpoint of relevant legal aspects ...." 


\section{MATTERS OF COMMON CONCERN HAVING LEGAL IMPLICA- TIONS}

\subsection{The United Nations Conference on Environment and Development: follow-up}

44. The Committee had before it a document prepared by the Secretariat under the title of the item, containing notes on the outcome of the first Conference of the Parties to the Convention on Biological Diversity held in the Bahamas from 28 November to 9 December 1994; on progress made following adoption of the UN Convention to Combat Desertification, which had been signed at Paris on 14 and 15 October 1994 by some 87 States and one regional organization; the convening of a Global Conference on Sustainable Development of Small Island Developing States at Bridgetown, and the Barbados Declaration and Programme of Action adopted at the Conference; and the Second Session of the UN Commission on Sustainable Development, held in New York in May 1994. The Assistant Secretary-General, introducing the item, observed that on two crucial issues, viz. the financial mechanism and transfer of technology to the developing countries, much remained to be done. He outlined the Secretariat's work programme, but noted that due to financial constraints AALCC staff had been unable to attend environmental meetings. He said that the document contained no information on the Framework Convention on Climate Change, since the first meeting of the Conference of the Parties to that Convention was to convene in Berlin from 28 March to 7 April 1995 , leaving no time for preparation of a note prior to the present Session.

45. The delegate of the Philippines, reporting on the first meeting of the Conference of the Parties to the Framework Convention on Climate Change which had recently concluded its work in Berlin, said that the substantive matters taken up at the Conference were (1) adequacy of commitments, (2) joint implementation, (3) the "financial mechanism", and (4) transfer of technology.

46. The delegate of Sudan observed that several countries had made reservations when ratifying the Convention on Biological Diversity, and requested the AALCC Secretariat to examine those reservations, and advise Members concerning their effects.

47. The delegate of China recalled that there had been consensus on the principle that resources and the environment should be harmonized with 
economic development, so as to bring society and economy on to a path of sustainable growth. In his view, however, the efforts made by the developed countries in particular, had fallen short of what was required for the effective implementation of the decisions of the UN Conference on Environment and Development. He expressed the hope that they would meet their original commitments to provide new and additional financial resources, and to transfer environmentally sound technologies under the most favourable terms to the developing countries. He recalled that the Framework Convention on Climate Change had as its objective "stabilization of greenhouse gas concentrations in the atmosphere at a level that would prevent dangerous anthropogenic interference with the climate system" (Article 2); stipulated that developed country Parties should take the lead in combating climate change and its adverse effects; and forged a global partnership whereby developed countries had the responsibility to provide financial and technological assistance to the developing countries to help the latter to comply with their obligations. He found that one year after the entry into force of the Convention the developed countries had not adequately complied with their obligations, and had failed to honour their commitment either to provide new and additional financial resources, or to transfer technology.

48. Continuing, the delegate of China said that in his view, under the Convention's provisions on "joint implementation" (Article 4, sub-paragraphs 2(a) and (d)), participation by a developing country Party in pilot joint implementation activity was to be on a voluntary basis. He stressed that "joint implementation" could only be regarded as an auxiliary means by which developed countries could implement the Convention, their main commitment being to reduce the emission of greenhouse gases by adopting domestic measures. Developed country Parties could not shift their emission limitation commitments on to developing country Parties by means of joint implementation, nor could the funds and technology applied by a developed country in such projects be interpreted as being in part fulfilment of its general commitment under the Convention to transfer funds and technology. "Joint implementation” was a means whereby developing country Parties could assist a developed country Party to implement the Convention. Such projects were to be carried out voluntarily, on the basis of equality and with full respect for the sovereignty of the developing countries.

49. As to the Convention on Biological Diversity, the delegate of China called on the developed country Parties to fulfil their commitment to provide new and additional financial resources to enable developing country Parties to meet the agreed full incremental costs to them of measures to implement the Conven- 
tion. In his view, the amount of the funds required should be decided by the Conference of the Parties, and should be raised by the future financial mechanism in accordance with its replenishment procedure. As an interim financial mechanism, GEF should set the ratio of funds to be used to implement the Convention and take immediate measures to ensure that such funds would be obtained.

50. Concluding, the delegate of China expressed the view that the $U N$ Convention to Combat Desertification would facilitate international cooperation in this field. Observing that rights and obligations under the Convention were uneven, in that the developed country Parties did not undertake substantive obligations under it to provide financial resources, he appealed to all countries and to the developed countries in particular, to fulfil the commitments made in this regard at the Rio Summit, because only by that means could desertification be halted.

51. The delegate of Republic of Korea said that transfer of technology, either from the public or private domain should present no problems, although transfer from the latter could raise intellectual property issues. He suggested that AALCC might identify any problems associated with transfer of publiclyowned technology and prepare guidelines on the subject.

52. The delegate of Kuwait said that her Government had participated actively both in the Intergovernmental Negotiating Committee on Climate Change, and the recently concluded Berlin meeting of the Conference of the Parties to the Framework Convention on Climate Change. She recalled that the important issues addressed by her Government's delegation, had been the need for the Bureau of the Conference to include a representative of the developing oilproducing countries, to protect the interests of that small, vulnerable group; the adoption of protocols by consensus; that "joint implementation" should be carried out strictly between developed countries; and the inadequacy of measures taken by the developed countries to implement their obligations under the Convention.

53. The delegate of Sri Lanka said that the main cause of environmental degradation in the developed countries was the high level of consumption in the developed countries, while poverty, under-development and lack of resources caused such degradation among the developing countries. He stressed that, while protection of the environment might be the common responsibility of the international community as a whole, the developed countries had a particular responsibility to take corrective measures. 
54. The delegate of India said that the UN Conference on Environment and Development had resulted in recognition of the concept of 'sustainable development', which brought together the concepts of economic development and environmental protection, and had laid the foundation for a global partnership in which all countries, developed and developing, had roles to play. He observed that it was difficult for the developing countries adequately to pursue enlightened environmental approaches in their programmes of development when protectionism was on the rise, the debt burden was increasing and the terms of trade deteriorating, resulting in reverse financial flows.

55. Continuing, the delegate of India said that environmental standards applicable in developed countries could have inappropriate and unwarranted social or economic costs if applied in developing countries, and that the formulation of 'harmonized' or 'global' environmental standards or their uniform application in the developing countries might not be feasible. Accordingly, in his view, development strategies undertaken in pursuance of 'sustainable development' were a matter for national decision-making, and the role of international co-operation should be to support and supplement such efforts, not to supplant them. The review of national policies or plans by external agencies, and the imposition of mandatory guidelines in sectors such as forestry or energy, would not be acceptable.

56. The delegate of India stressed that the integration of environmental concerns into economic development policies and programmes should be carried out without introducing any new form of conditionality in aid or development financing, and the principle should not be used as a pretext for erecting new trade barriers. It was also important that new and additional funding should be provided and should include multilateral funding, and that multilateral funding institutions or mechanisms should be administered democratically and not dominated by donor countries. Moreover, the provision of adequate funds would not, by itself suffice: the transfer of environmentally sound technologies to countries in need of them, should also be ensured.

\section{Decision}

57. Discussion of the item (Report, pp. 78-87) was followed by adoption of an essentially procedural decision (Report, p. 104). 


\subsection{United Nations Decade of International Law}

58. The Committee had before it a document prepared by the Secretariat under the title of the item (Doc. No. AALCC/XXXIV/DOHA/95/8) which recounted the history of the item, and the various activities undertaken or promoted by AALCC in connection with it. The Secretary-General, introducing the item recalled that, since the Committee's Tokyo meeting, AALCC had contributed a report on its activities to the Congress on Public International Law held at UN headquarters in March 1995, and had organized seminars on the Status and Treatment of Refugees, the proposed International Criminal Court, and the Globalization and Harmonization of Commercial and Arbitration Laws. He said that a seminar on the Role and Work of the International Court of Justice was planned for September 1995, to commemorate its Fiftieth Anniversary.

59. The delegate of Iran said that it was imperative that all Members of AALCC endeavour to promote the objectives of the Decade and to facilitate successful implementation of its programmes which were directed at upholding the supremacy of law in international relations. He recalled that the proposal made by his delegation in the Sixth Committee of the General Assembly in 1992, to convene a Congress on Public International Law had received wide support, and had been successfully implemented in March 1995, attracting representatives of institutions, and experts in international law from all over the world. He emphasized the role of AALCC as a regional organization with responsibility for promoting the progressive development and codification of international law, and observed that the Committee was fulfilling its mandate inter alia through persuading Member States to give serious attention to the observance of the Decade, and assisting those Members who had not yet acceded to or ratified key multilateral conventions, to do so.

\section{Decision}

60. Discussion of the item (Report, pp. 87-90) was followed by adoption of an essentially procedural decision (Report, pp. 105-6).

\section{3. 'Agenda for Peace'}

61. The Committee had before it a document entitled 'Agenda for Peace: Convention on the Safety of United Nations and Associated Personnel' (Doc. No. AALCC/XXXIV/DOHA/95/9) prepared by the Secretariat, recounting the 
history of consideration of the item by AALCC, and containing an overview of the work of the Ad hoc Committee to elaborate an international convention dealing with the safety and security of United Nations and associated personnel, with particular reference to responsibility for attacks on such personnel, established following initiatives taken by New Zealand and Ukraine during the 48th Session of the General Assembly in 1993 (Resolution 48/37, adopted 9 December 1993), and culminating in adoption of the United Nations Convention on the Safety of United Nations and Associated Personnel during the 49th Session of the General Assembly. The Secretariat's overview concludes with the "General Comments" reproduced below.

“. . .

\section{GENERAL COMMENTS}

43. Over the last few years, there has been increasing involvement of the United Nations in dealing with crises and conflict situations. There are as many as 16 peace-keeping operations where the United Nations has deployed nearly 75,000 personnel both civilian and military. The number of violent attacks and commission of other types of crimes against these personnel have increased many-fold.

44. The Convention on the Safety of United Nations and Associated Personnel provides a useful legal framework.

45. The Convention would apply to any operation mandated by the United Nations whether it is peace-keeping or humanitarian. It would extend its coverage to the different categories of United Nations personnel, including military personnel, police personnel and civilian personnel. Such a broad coverage is in line with the increasing involvement of the United Nations in various kinds of operations. The involvement of non-governmental organizations and its personnel in any United Nations operations should be carefully executed.

46. It is the established practice to seek consent of the host State prior to the beginning of any United Nations operation in the concerned State. Problems, however, could arise where because of the circumstances, the host government may not be in full control of the situation. Similarly, whether the situation is one of an international character, or is non-international, armed conflict would also pose difficulties in obtaining such a consent.

47. The States which agree to send their military personnel to join the UN operation do it on a voluntary basis. The provisions of the United Nations 
Charter impose no such obligation. It has been the practice of the United Nations to conclude bilateral agreements with the concerned states on the basis of status-of-forces agreements. Of late, it has been a model for concluding bilateral agreements for the deployment of civilian personnel as well. It is for consideration whether the personnel deployed pursuant to a mandated United Nations operation should remain under the command and control of the United Nations. While it is recognized that there is a certain distinction between the direct operations of the UN and UN authorized operations, recent events have shown that unilateral withdrawal of the military contingents by certain States put the entire United Nations operation in jeopardy. Such a situation would pose grave risks for the safety and security of other United Nations personnel engaged in that operation.

48. The main thrust of the Convention is to establish the duty of States to take all appropriate measures to ensure the safety and security of the United Nations personnel. The host state, in particular would assume the responsibility to protect United Nations personnel who are deployed in its territory from attacks or other acts of violence. The host State should give due respect to the international character of the United Nations operation, respect the privileges and immunities of the United Nations and of United Nations personnel, and take all necessary measures to ensure the safety and security of the personnel deployed to carry out that operation;

49. Article 105(1) of the United Nations Charter stipulates that "The organization shall enjoy in the territory of each of its Members such privileges and immunities as are necessary for the fulfilment of its purposes". Further, the General Convention on the Privileges and Immunities of the United Nations, approved by the General Assembly on 13 February 1946 and the Convention on Privileges and Immunities of the Specialized Agencies approved on 21 November 1947 elaborate provisions dealing with the privileges and immunities of the United Nations and the Specialized Agencies respectively. 'Statusof-forces' agreements incorporate relevant provisions from these Conventions and provide for certain privileges and immunities of the military and civilian personnel deployed in the United Nations operations. Further, as regards the civilian contractors and non-governmental organizations and their personnel who are engaged in United Nations operations through contractual or other arrangements, it may be pointed out that the Security Council in its resolution 868 of 29 September 1993 , decided that the safety and security arrangements undertaken by the United Nations or the host country should extend to all persons engaged in operations authorized by the Security Council (A/Ac.242/ 1, para 12). A word of caution is necessary in this regard. Extension of privileges and immunities to such a wide category of people may open the door to its abuse. Identification of such personnel and keeping their track record will not be an easy thing, especially when they are engaged in 
humanitarian operations. If proper measures are not taken, there might exist a certain risk of undermining the rights of sovereign states. The host government may not agree to extend privileges and immunities to locally recruited employees, or to any non-governmental organizations whose credibility is questionable.

62. The delegate of Japan welcomed the adoption of the Convention on the Safety of United Nations and Associated Personnel as a step toward increased international co-operation in protecting both UN peacekeeping personnel and others involved in humanitarian activity, including the personnel of nongovernmental organizations supporting the work of the United Nations; and in establishing a framework for the prosecution and punishment of those violating the law. He urged that a declaration by the Security Council or the General Assembly provided for in Article 1, sub-paragraph (c)(ii) of the Convention be utilized to ensure the applicability of the Convention to such personnel, emphasizing that it was of crucial importance that the co-operation of the host State in any such measures, be obtained.

63. Continuing, the delegate of Japan said that his Government had contributed \$2.5 million to the Cambodia Mine Action Centre in March 1994. He said that his Government, convinced of the importance of such initiatives, would continue to support the current preparations for a review conference on the Convention on Prohibitions or Restrictions on the Use of Certain Conventional Weapons, in order to restrict the use of anti-personnel mines and promote acceptance by the international community of obligations regarding mine clearance. He said his Government welcomed the "Supplement" to $A n$ Agenda for Peace, and expressed the hope that the principles set forth therein would be respected as being elements essential to the success of peace-keeping operations.

\section{Decision}

64. Discussion by the Committee (Report, pp. 90-92) was followed by an essentially procedural decision (Report, p. 107). 


\subsection{Trade Law: Progress Report concerning the Legislative Activities of the United Nations and Other International Organizations in the field of International Trade Law}

65. The Committee had before it two documents prepared by the Secretariat: the first, with the title of the item, focussed on the activities of UNCITRAL, UNCTAD, UNIDO, and UNIDROIT (Doc. No. AALCC/ XXXIV/DOHA/ 95/10); and the second was the Report on the International Seminar on Globalization and Harmonization of Commercial and Arbitration Laws, held at New Delhi from 31 March-1 April 1995 (Doc. No. AALCC/XXXIV/ DOHA/95/10A). The Committee also had before it two other documents prepared by the Secretariat: Report of the Secretary-General on the Progress made by the Data Collection Unit (Doc. No. AALCC/XXXIV/ DOHA/95/14) on the activities of the Committee's Data Collection Unit financed by the Republic of Korea; and Progress Report on AALCC's Regional Centres for Arbitration, on the work of arbitration centres located at Kuala Lumpur, Cairo and Lagos, and proposals for establishment of a regional arbitration centre in Teheran (Doc. No. AALCC/XXXIV/DOHA/ 95/15). A detailed report on the work of the Cairo Regional Arbitration Centre is included as part XII of the Committee's Report (pp. 109-126).

\subsubsection{Trade Law: the New GATT Accord}

66. The Committee had before it a document prepared by the Secretariat entitled "The New GATT Accord: an overview with special reference to the World Trade Organization (WTO), trade-related investment measures (TRIMS) and trade-related aspects of intellectual property rights (TRIPS)" (Doc. No. AALCC/XXXIV/DOHA/95/11).

\section{Decision}

67. The Committee, having considered together the Trade Law items referred to under heads 4.4 and 4.4.1 above (Report, pp. 75-8), adopted an essentially procedural decision (Report, p. 108). 